Research review paper

\title{
Voltammetric aptasensors for protein disease biomarkers detection: A review
}

\author{
Sofia G. Meirinho ${ }^{\mathrm{a}, *}$, Luís G. Dias ${ }^{\mathrm{b}, \mathrm{c}}$, António M. Peres ${ }^{\mathrm{d}}$, Lígia R. Rodrigues ${ }^{\mathrm{a}}$ \\ a Centre of Biological Engineering (CEB), University of Minho, Campus de Gualtar, 4710-057 Braga, Portugal \\ ${ }^{b}$ ESA, Instituto Politécnico de Bragança, Campus Santa Apolónia, 5300-253 Bragança, Portugal \\ c CQ-VR, Centro de Química - Vila Real, University of Trás-os-Montes e Alto Douro, Apartado 1013, 5001-801 Vila Real, Portugal

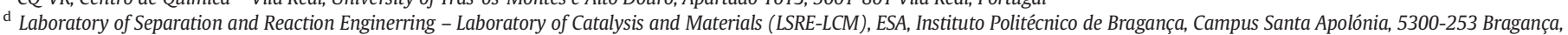 \\ Portugal
}

\section{A R T I C L E I N F O}

\section{Article history:}

Received 17 November 2015

Received in revised form 20 May 2016

Accepted 22 May 2016

Available online 24 May 2016

\section{Keywords:}

SELEX

Aptamers

Electrochemical

Voltammetric

Aptasensors

Protein biomarkers

\begin{abstract}
A B S T R A C T
An electrochemical aptasensor is a compact analytical device where the bioreceptor (aptamer) is coupled to a transducer surface to convert a biological interaction into a measurable signal (current) that can be easily processed, recorded and displayed. Since the discovery of the Systematic Evolution of Ligands by Enrichment (SELEX) methodology, the selection of aptamers and their application as bioreceptors has become a promising tool in the design of electrochemical aptasensors. Aptamers present several advantages that highlight their usefulness as bioreceptors such as chemical stability, cost effectiveness and ease of modification towards detection and immobilization at different transducer surfaces. In this review, a special emphasis is given to the potential use of electrochemical aptasensors for the detection of protein disease biomarkers using voltammetry techniques. Methods for the immobilization of aptamers onto electrode surfaces are discussed, as well as different electrochemical strategies that can be used for the design of aptasensors.
\end{abstract}

(c) 2016 Elsevier Inc. All rights reserved.

\section{Contents}

1. Introduction ......... 942

2. Aptamer-based biosensors: aptasensors. . . . . . . . . . . . . . . . . . . . . . . . . . . . . . . 942

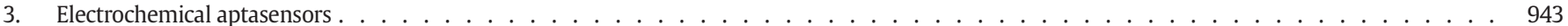

3.1. Electrode surface. . . . . . . . . . . . . . . . . . . . . . . . . . . . . . . 944

3.2. Immobilization of the aptamers . . . . . . . . . . . . . . . . . . . . . . . . . . . . . . . . 944

3.3. Design strategies. . . . . . . . . . . . . . . . . . . . . . . . . . . . . . . . . . . . . . . . . . . . . . . . . .

3.4. Labelled electrochemical aptasensors . . . . . . . . . . . . . . . . . . . . . . . . . . . . . . . . . . 946

3.4.1. Aptasensors based on target binding-induced aptamer conformation . . . . . . . . . . . . . . . . . . . . . . . . . . . . . 949

3.4.2. Aptasensors based on sandwich design . . . . . . . . . . . . . . . . . . . . . . . . . . . 948

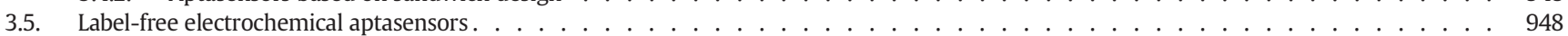

3.5.1. Aptasensors based on target binding-induced aptamer conformation . . . . . . . . . . . . . . . . . . . . . 948

3.5.2. Aptasensors based on target binding-induced aptamer dissociation/displacement . . . . . . . . . . . . . . . . . . . 949

3.6. Use of nanomaterials in electrochemical aptasensors . . . . . . . . . . . . . . . . . . . . . . . . . . . . . . . . . 950

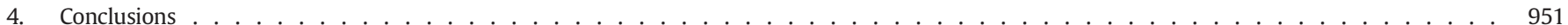

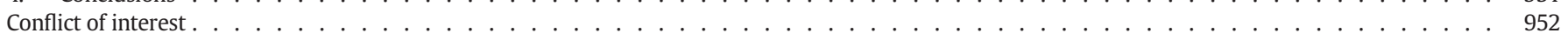

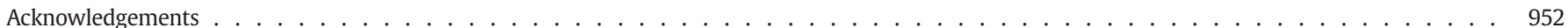

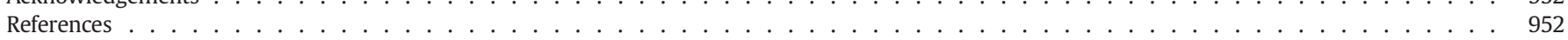

* Corresponding author at: University of Minho, Campus de Gualtar, 4710-057 Braga, Portugal.

E-mail address: smeirinho@deb.uminho.pt (S.G. Meirinho). 


\section{Introduction}

In biomedical applications, the development of methodologies to detect and quantify proteins, specifically protein biomarkers, has increasingly become essential for areas such as clinical analysis, detection and treatment of certain diseases that can be correlated with changes in concentration of a protein biomarker in biological fluids. Determining the amounts of specific proteins in a given sample is particularly interesting and challenging. These proteins are effective diagnostic and prognostic tools for many diseases depending on the capability of easily quantifying their low concentrations in biological samples (Csordas et al., 2010; Hanash, 2011). Several strategies have been pursued to develop accurate and simple diagnosis methodologies, using different recognition elements (e.g. antibodies, aptamers) and different sensing principles and techniques (e.g. optical, electrochemical). Up to now, a variety of aptamers exhibiting high selectivity and affinity towards relevant protein disease biomarkers have been reported, thus allowing the fabrication of new, simple and sensitive diagnostic methods to determine such proteins in standard solutions and in complex samples such as blood and serum. The use of electrochemical aptasensors is particularly interesting given their simplicity, sensitivity, specificity and suitability for the detection of low levels of protein disease biomarkers using several available techniques including cyclic voltammetry (CV), square-wave voltammetry (SWV) and differential pulse voltammetry (DPV). Commonly, thrombin is used as a model protein in the design of aptasensors. However, other disease-related proteins such as platelet-derived growth factor (PDGF), osteopontin (OPN), vascular endothelial growth factor (VEGF) and Mucin 1 (MUC1) have been broadly described. These proteins can be associated to several diseases and have been found in many cancers, but particularly in breast cancer. Globally, cancer is a relevant health risk given the amount of persons annually diagnosed with this disease, thus progress leading to enhanced survival is a global priority. For instance, breast cancer is the most prevalent cancer in women worldwide and its cancer-related mortality is closely associated with the metastatic potential of the primary tumor (Xu et al., 2015), accounting for 25\% (1.67 million) of the all cancer cases and 15\% $(522,000)$ of the cancer deaths. Despite the efforts to reduce the number of cases, breast cancer metastasis and breast cancerrelated mortality, the prognosis remains poor (Xu et al., 2015), thus reinforcing the relevance of developing new diagnostic methods with improved features, including high specificity and sensitivity, low cost, suitability for prognosis and disease monitoring. Therefore, in this review, a special emphasis is given to the potential use of electrochemical aptasensors for the detection of protein disease biomarkers (e.g. breast cancer biomarkers) using voltammetry techniques.

\section{Aptamer-based biosensors: aptasensors}

According to the International Union of Pure and Applied Chemistry (IUPAC) "a biosensor is a self-contained integrated device which is capable of providing specific quantitative or semi-quantitative analytical information using a biological recognition element (biochemical receptor) which is in direct spatial contact with a transducer element" (Thévenot et al., 1999, 2001). Another definition commonly used for biosensors is "analytical devices that are based on a bioreceptor and that are capable of sensing biologically-relevant analytes with either electrical or optical readout" (Cheng et al., 2009). As illustrated in Fig. 1 , the main components of biosensors are the bioreceptors or biorecognition elements; transducers or the detection devices; and displays or electronic parts comprised by a signal amplifier and the data processor (Cheng et al., 2009; Strehlitz et al., 2008; Velusamy et al., 2010). The basic principle of the biosensor detection is the specific binding of the target of interest to the bioreceptor immobilized on a suitable support matrix, usually an electrode, to produce either discrete or continuous signals, which are proportional to a property of a single target or a related group of analytes. The signals are then transformed into a digital format that can be recognized by the end users (Strehlitz et al., 2008). The bioreceptor will be responsible for the selectivity/specificity of the sensor response to a given target or group of targets of interest, thus minimizing the interference from other substances in complex mixtures (Viswanathan and Radecki, 2008). On the other hand, the transducer determines the sensitivity of the biosensor and is responsible for converting the biological signal into a measurable signal (Monošík et al., 2012; Sassolas et al., 2009). The selectivity and sensitivity of the bioreceptor and transducer make the biosensors an attractive analytical tool in several areas and applicable to a large variety of samples including body fluids, food, cell cultures and environmental samples (Cheng et al., 2009; Grieshaber et al., 2008; Sassolas et al., 2009).

Biosensors that use DNA or RNA aptamers as bioreceptors have been named "aptasensors" (Cheng et al., 2009; Hianik and Wang, 2009; Radi, 2011; Sassolas et al., 2009). The aptasensors emerged in the early 1990s with the discovery and introduction of aptamers as sensing probes (Ellington and Szostak, 1990; Tuerk and Gold, 1990 cited in Cheng et al., 2009). Indeed, these were then considered an important alternative to the classical analytical methods for protein detection. Aptamers are short nucleic acids ( $\approx 12-80$ nucleotides long) of RNA or single-stranded DNA that possess unique binding characteristics to their targets, such as high sensitivity/affinity, specificity and ability to fold into numerous tertiary conformations (e.g. hairpin, G-quartet, stem-bulge, pseudoknot, T-junction) (Cho et al., 2009; de-los-Santos-Álvarez et al., 2008; Famulok and Mayer, 2011; Lakhin et al., 2013; Meyer et al., 2011; Radom et al., 2013). Several aptamers have been selected against a large variety of targets including proteins, ions, toxins, drug molecules, cells, and tissues (Lee et al., 2008; Shamah et al., 2008; Stoltenburg et al., 2007), through an in vitro selection procedure known as SELEX (Systematic Evolution of Ligands by Exponential Enrichment) (Fig. 2).

The SELEX methodology starts with a chemically synthesized random oligonucleotides library (up to $10^{15}$ different sequences). As illustrated in Fig. 2, the selection process may be divided into 3 steps, namely binding, separation/partitioning and amplification, which are iteratively repeated to obtain nucleotides with improved binding ability towards the desired target. After a number of cycles (generally 5-

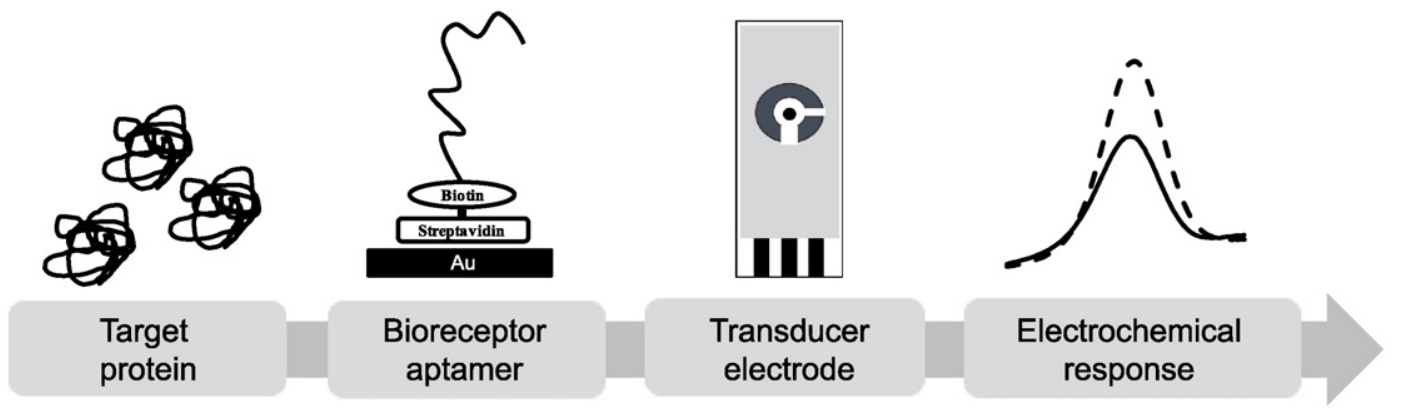

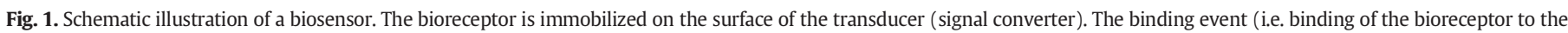
target molecule) is then transformed into a measurable signal by the transducer, which leads to a measurement unit within the electronic device. 


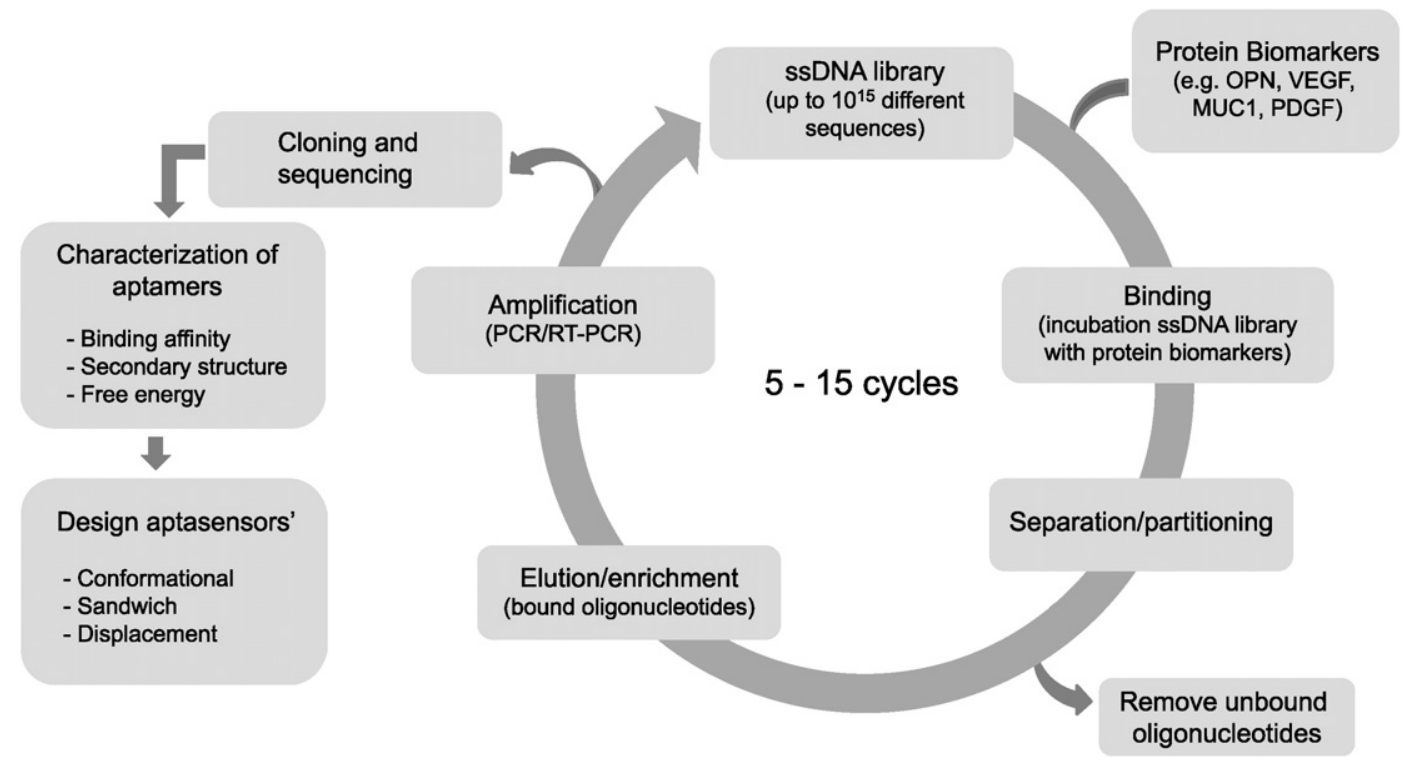

Fig. 2. Systematic Evolution of Ligands by Exponential Enrichment (SELEX) methodology.

15 cycles), the sequences obtained are cloned, sequenced and their binding affinity, secondary structure and Gibbs energy are evaluated in order to select the aptamers with high affinity and specificity to the target molecule (Darmostuk et al., 2015; Dua et al., 2011; Radom et al., 2013; Santosh and Yadava, 2014; Song et al., 2012; Syed and Pervaiz, 2010; Vikesland and Wigginton, 2010). The specific properties of aptamers as bioreceptors in the development of aptasensors offer some advantages over methods that are mainly based on standard affinity receptors (e.g. antibodies), such as high selectivity and affinity, easier artificial synthesis, chemical stability under a wide range of buffer conditions, resistance to harsh treatments without loss of bioactivity, reversible thermal denaturation, adaptability to various targets, ease of storage, and versatility in labeling, immobilization, signaling and regeneration (Feng et al., 2008; Hianik and Wang, 2009; Li et al., 2011a; Radi, 2011; Strehlitz et al., 2008). Indeed, the small size of aptamers allows their efficient immobilization at high densities in different surfaces. Thus, production, miniaturization, integration and automation of biosensors can be accomplished more easily with aptamers than with antibodies (Strehlitz et al., 2008). Altogether these properties make aptamers an appropriate tool in the development of aptasensors (de-los-Santos-Álvarez et al., 2008; Guo et al., 2008; Hianik and Wang, 2009; Lee et al., 2008; Park et al., 2009; Song et al., 2008, 2012; Tombelli et al., 2005; Velasco-Garcia and Missailidis, 2009; Zhang and Chen, 2010). Additional advantages include the possibility of performing several analysis with mild changes of the binding specificity and selectivity; along with the possibility of using different designs and detection strategies for fast and easy detection of protein in real biological samples (Cheng et al., 2009; Hianik and Wang, 2009; Hianik et al., 2007; Kim et al., 2008; Nguyen et al., 2009; Song et al., 2008; Zhou et al., 2011). The lack of specific aptamers for the majority of protein disease biomarkers, as well as the existence of few aptamers with two recognition sites for a single target, may limit the development of aptasensors. Nevertheless, over the years with the use of different SELEX methodologies, a large number of aptamers have been isolated and used to develop aptasensors for the detection of small molecules and protein disease biomarkers.

The large scale production of aptasensors is subject to some hurdles that must be overcome, such as the aptamer stability during immobilization and the signal detection in complex biological samples, mainly due to the interferences from other molecules that are also present in those samples (Hianik and Wang, 2009; Hianik et al., 2007). In biosensing applications, DNA aptamers are suitable for designing reusable aptasensors, whereas RNA aptamers allow single shot measurements since they are more susceptible to nucleases attack (Sassolas et al., 2009; Strehlitz et al., 2008). However, some chemical modifications can enhance nuclease resistance (i.e. aptamers biostability in serum) and increase the half-life of aptamers (Kuwahara and Sugimoto, 2010; Stoltenburg et al., 2007).

In summary, the detection of cancer biomarkers at an early stage allows a better diagnosis, together with the definition of more adequate treatments that ultimately will lead to an increased survival. The selection and design of aptamers that are specific to recognized cancer biomarkers (e.g. OPN, MUC1, VEGF) can represent a good alternative for diagnostic and treatment of the disease. In this review some electrochemical transducers for the detection of proteins are discussed, as well as methods of immobilization of aptamers and the detection strategies used in the production of electrochemical (voltammetric) aptasensors.

\section{Electrochemical aptasensors}

Electrochemical aptasensors use an electrode surface to immobilize the aptamer and hold an electrochemical transducer to monitor the aptamer-target interaction, by detecting current or potential changes that occur at the transducer/bioreceptor interface/surface (Hong et al., 2012; Monošík et al., 2012; Sadik et al., 2009; Thévenot et al., 1999, 2001). The electrochemical transduction presents considerable advantages over optical, piezoelectric or thermal detection (Deng et al., 2013a; Radi, 2011), such as high sensitivity and selectivity, the ability to work with turbid samples, compatibility with novel microfabrication technologies, inherent miniaturization, disposability and accuracy, simplicity, robustness, possibility of usage for on-line control, fast response, and relatively low manufacturing cost; thus making electrochemical aptasensors extremely attractive for diagnostic and use in point-ofcare devices, in addition to simultaneous multi-analyte detection (Arshak et al., 2009; Radi, 2011; Saberian et al., 2011; Song et al., 2008; Velasco-Garcia and Missailidis, 2009; Velusamy et al., 2010; Xu et al., 2009).

The first aptasensor for the detection of a target protein at nanomolar levels was reported in 1998, using a DNA aptamer against thrombin (as previously mentioned, a model protein commonly used in the design of aptasensors) (Potyrailo et al., 1998 cited by Zhou et al., 2011). Later, Hianik et al. (2005) described the first voltammetric aptasensor using DNA aptamers against thrombin immobilized onto a 
gold electrode surface. This biosensor detected the thrombin-aptamer interactions through the measurement of charge changes by differential pulse voltammetry (DPV) and using methylene blue (MB) as the electrochemical indicator. The electrochemical transduction of biosensors using aptamers as bioreceptors can be divided in voltammetric, amperometric, potentiometric, impedimetric and conductometric, depending on the measurable parameters such as current and potential, current, potential, impedance, and conductance, respectively (Arshak et al., 2009; Velusamy et al., 2010). Among voltammetric biosensors, different voltammetry techniques can be used such as CV, DPV, SWV and alternating current voltammetry (ACV). The voltammetric and/or amperometric biosensors are characterized by applying a potential to a working electrode versus a reference electrode. The corresponding current is a result of electrolysis by means of an electrochemical reduction or oxidation at the working electrode. Amperometric biosensors may be considered a subclass of voltammetric biosensors since they operate under an imposed constant potential (voltage) that is maintained at the working electrode with respect to a reference electrode, being the change in current monitored as a function of time. On the other hand, in the voltammetric biosensors the potential is scanned over a set potential range and both the current and potential are measured and recorded. For amperometric and voltammetric biosensors, the recorded current response is proportional to the concentration of the target molecule in the sample (Grieshaber et al., 2008; Kumar and D'Souza, 2012; Liu, 2000; Rahman et al., 2008; Ronkainen et al., 2010; Viswanathan and Radecki, 2008). A remarkable advantage of voltammetric biosensors is the low related noise observed, hence providing reliable and reproducible data for the quantification of a target molecule, which can endow the biosensor with higher sensitivity and specificity. In addition, voltammetry allows the detection of multiple compounds, which have different peak potentials, in a single electrochemical experiment (or scan), thus offering the possibility of simultaneously detecting multiple analytes (Marks and Abdulhalim, 2015). Among the voltammetric aptasensors, those based on CV, DPV and SWV are the most frequently used. However, the CV technique can be used to evaluate the electrode surface, namely its purity, stability, reproducibility and repeatability. CV may also be used for cleaning and for monitoring the immobilization of aptamers on the electrode surface since it allows a fast visualization of the redox behavior over a wide potential range (Ferreira et al., 2011). Moreover, it can also be used to study the performance of an electrochemical aptasensor during the detection of several molecules, such as proteins (Cheng et al., 2007; Meirinho et al., 2015; Wang et al., 2009; Yuan et al., 2011).

The electrochemical aptasensors can be applied in several areas such as health (specifically in clinical diagnostic and for therapeutic purposes), food industry and environmental monitoring for the detection of protein disease biomarkers, pathogens and small molecules, respectively (Hayat and Marty, 2014; Hong et al., 2012; Kim and Gu, 2014; Labib and Berezovski, 2014; Liu et al., 2012; Palchetti and Mascini, 2012; Sett et al., 2012). The application of electrochemical aptasensors for clinical diagnosis, particularly for the detection of protein disease biomarkers, which is an emergent field of research, is herein discussed as previously mentioned.

\subsection{Electrode surface}

The electrode/transducer surface (e.g. thickness and stability of the materials), the immobilization method and the detection technique are relevant factors that must be considered whenever developing an electrochemical aptasensor (Zhang et al., 2000). Usually, a three-electrode configuration is included in the surface of a voltammetric aptasensor, namely the working, auxiliary or counter and the reference electrodes (Lim et al., 2010). The common material used as the working electrode surface is carbon and noble metals, for which different immobilization strategies and detection approaches can be applied. Metals such as gold, platinum, silver and stainless steel have long been used for electrochemical electrodes due to their excellent electrical and mechanical properties (Hayat and Marty, 2014; Ronkainen et al., 2010; Zhang et al., 2000). Other electrode surfaces can be used in the development of electrochemical aptasensors, such as screen printed electrodes (SPE), glassy carbon electrodes (GCE), carbon paste electrodes (CPE), depending on the target molecule to be detected. The use of the latter allows the miniaturization of the biosensor, as well as reducing the volume of samples and reagents down to a few microliters. In addition, these sensors avoid the contamination between samples and exhibit a reproducible sensitivity (Ronkainen et al., 2010; Tothill, 2009; Wei et al., 2009).

\subsection{Immobilization of the aptamers}

Another essential step in the development of electrochemical aptasensors is the immobilization of the aptamer, which plays a major role in the overall biosensor performance. The stability, affinity and specificity of the aptamer towards the target molecule depend on the technique used to immobilize it onto the electrode/transducer surface. Thus, it is crucial to treat and control the surface to assure high reactivity, orientation/accessibility and stability of the surface-bound aptamer, as well as to minimize non-specific binding/adsorption phenomena (Hianik and Wang, 2009; Lim et al., 2010). The choice of the immobilization method depends on several factors, such as the nature of the bioreceptor and electrode/transducer surface, the physicochemical properties of the target molecule and the operating conditions of the biosensor. Therefore, the selected method should ensure that the binding affinity and selectivity of the aptamers in solution are kept in order to obtain the maximum activity whenever they are immobilized as the bioreceptor (Balamurugan et al., 2008; Velasco-Garcia and Missailidis, 2009). The immobilization methods usually applied are physisorption (physical adsorption), chemisorption (chemical adsorption), streptavidin/avidin/neutravidin-biotin interaction and covalent attachment via functional groups (Balamurugan et al., 2008; de-los-Santos-Álvarez et al., 2008; Sassolas et al., 2009; Zhou et al., 2011) (Fig. 3). In the first method, no aptamer modification is required and the aptamer is immobilized on the electrode surface by means of electrostatic forces. This method is simple but, in general, it is not suitable for the development of reusable aptasensors due to the low stability resulting from the aptamers' desorption from the surface (Hianik and Wang, 2009; Paniel et al., 2013; Radi, 2011; Sassolas et al., 2009). In the other three methods, the aptamers are modified with a thiol group (-SH), a biotin protein and a chemical functional group (e.g. amino groups $\left(-\mathrm{NH}_{2}\right)$ ), respectively (de-los-Santos-Álvarez et al., 2008; Zhou et al., 2011). Aptamers can be modified and attached to the electrode surface either by the $5^{\prime}$-end or the $3^{\prime}$-end. Both positions have been used to develop aptasensors, although very few studies evaluated the effect of the type of the aptamer's end position, used for the attachment to the surface, on the immobilization and aptasensor performances. However, some studies suggest that it depends on the particular aptamer, although the 3 '-end could be more suitable for biological targeting since it is the primary target for exonucleases and its binding to the solid support would simultaneously confer resistance to nucleases (Hayat and Marty, 2014; Hianik and Wang, 2009; Velasco-Garcia and Missailidis, 2009). These immobilization methods allow obtaining a stable, flexible and repeatable aptamer layer on the surface (Radi, 2011; Xu et al., 2009; Zhou et al., 2011).

The chemisorption method consists in the direct immobilization of the thiolated aptamer onto the electrode surface. It is a simple and effective method based on the strong affinity of thiol groups $(-\mathrm{SH})$ for gold electrode surfaces that enables the formation of covalent bonds between the sulfur and gold atoms forming a stable and flexible self-assembled monolayer (SAM) with repeatable aptamer surface layers (Paniel et al., 2013; Sassolas et al., 2009).

The immobilization of aptamers based on the streptavidin/avidin/ neutravidin-biotin interaction has been exploited based on the specific 


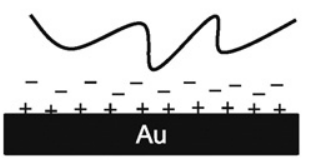

A

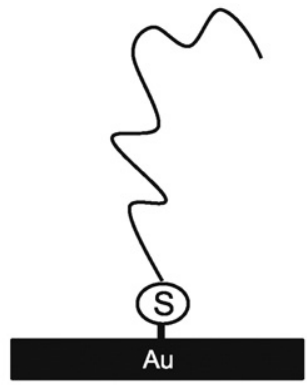

B

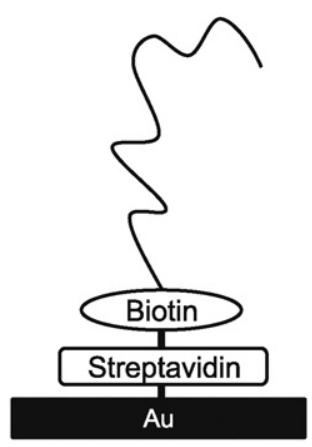

C

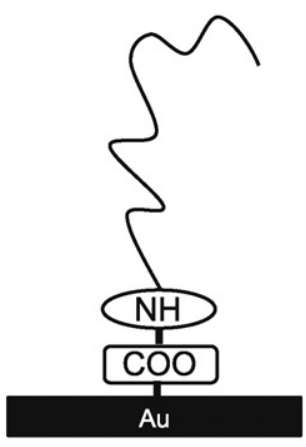

D

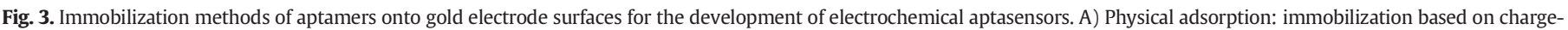

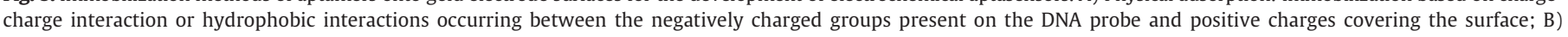

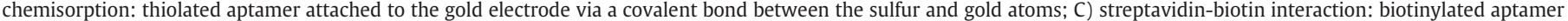

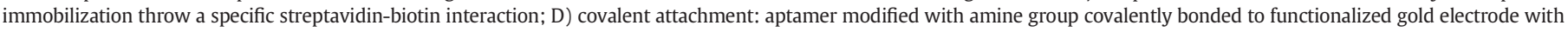
a functional group (e.g. an carboxylic acid group).

and strong affinity between streptavidin (or derivatives) and biotin. The streptavidin and avidin proteins have four identical binding sites for biotin (Chung et al., 2011; Hayat and Marty, 2014). However, the streptavidin is preferably used over avidin, leading to fewer non-specific interactions associated to the low isoelectric point (pI) (Lim et al., 2010; Sassolas et al., 2008, 2009). The streptavidin (or derivatives) can easily be linked on the electrode surface through physical adsorption or noncovalent bonding (Hianik et al., 2005, 2007; Nimse et al., 2014; Zhou et al., 2011). Other advantages can be pointed out, namely the need of very low amounts of biotinylated aptamer (Chung et al., 2011); the fact that it is less affected by changes of buffer concentration, $\mathrm{pH}$, denaturants and high temperatures; as well as the decrease of non-specific adsorption and improvement of the signal-to-noise ratio (Paniel et al., 2013; Zhou et al., 2011).

In the covalent attachment method, the electrode surfaces are modified with chemical groups (e.g. amine: $-\mathrm{NH}_{2}$; hydroxyl: $-\mathrm{OH}$; carboxylic acid: $-\mathrm{COOH}$; aldehyde: $-\mathrm{CHO}$ ) that interact with the modified aptamer exhibiting the corresponding chemical functional group to form an ordered aptamers layer on the electrode surface. Commonly, the amino $\left(-\mathrm{NH}_{2}\right)$-modified aptamer is covalently attached onto the electrode surface functionalized with thiolic acids and then the terminal carboxylic group $(-\mathrm{COOH})$ is activated with 1-ethyl-3-[3dimethylaminopropyl]-carbodiimide hydrochloride (EDC)/Nhydroxysulfosuccinimide (sulfo-NHS) (Balamurugan et al., 2008; Zhou et al., 2011). This method can be performed on different surfaces such as gold or platinum electrodes, glassy carbon, carbon pasta, silicate and polymer surfaces and, more recently, gold nanoparticles (AuNPs) and gold nanorods (AuNRs) (Zhou et al., 2011). However, the choice of the surface functionalization strategy to be implemented depends on the type of terminal functional groups linked to the aptamer (Balamurugan et al., 2008). This method allows increasing the specificity of the aptasensors and decreasing the non-specific adsorption (Paniel et al., 2013).

Another method that can be used is the application of the partially complementary sequences that are immobilized onto the electrode surfaces using one of the methods described above. In this case, the aptamers are immobilized by hybridization. However, in this method the experimental conditions are difficult to control since it involves annealing and hybridization steps (Han et al., 2009; Hianik and Wang, 2009). Whenever manufacturing aptasensors, it is important to evaluate how the immobilization methods can affect their performance regarding the detection of the target molecule. Hianik et al. (2007) evaluated the sensitivity of aptasensors using three aptamer immobilization methods, namely the bonding through affinity (avidin-biotin interaction), direct chemisorption of aptamers modified with -SH groups and polyamidoamine (PAMAM) dendrimers layers. The best results were obtained for the aptamer immobilization by means of avidin-biotin interaction, followed by the dendrimer layer and lastly the aptamer chemisorbed directly onto the gold surface. Similarly, Ostatná et al. (2008) demonstrated that the immobilization of the aptamers by means of the streptavidin-biotin interaction showed the best results regarding the sensor specificity and sensitivity.

\subsection{Design strategies}

Different design strategies may be adopted in the fabrication of electrochemical aptasensors depending on the envisaged use. These strategies (reviewed by Cheng et al. (2009) and Han et al. (2010)) can be divided into three or four types based on the differences in the design of the DNA/RNA-modified electrodes. Cheng et al. (2009) classified electrochemical aptasensors in three categories in which the analyte/target molecule detection relies on a configuration change (i.e. target binding induces either an assembly or dissociation of the aptamer); conformation change (i.e. target binding induces a modification in the conformation of the aptamer immobilized onto the surface); and conductivity change (i.e. target binding "switches on" the conductivity of the surface-bound aptamer-DNA). On the other hand, Han et al. (2010) suggested four possible design strategies, viz. target-induced structure switching mode; sandwich or sandwich-like mode; target-induced dissociation or displacement mode; and competitive replacement mode. Fig. 4 illustrates the main strategies/designs used in the development of electrochemical aptasensors. Regarding the electrochemical aptasensors detection, two main approaches have been used, namely the label (using labelled aptamers) and label-free (using non-labelled aptamers) approaches. The measurement of changes in the electrode surface of electrochemical aptasensors can be either "signal-on" (positive readout signal) or "signal-off" (negative readout signal), i.e. an increase or a decrease of the response following upon aptamer-target interaction, depending on the format of the assay used in the aptasensor fabrication (Hayat and Marty, 2014; Radi, 2011; Sassolas et al., 2009; Song et al., 2008; Strehlitz et al., 2008). However, the aptasensors based in "signal-off" are usually less sensitive, more susceptible to background variation and small signal changes (Zhou et al., 2014). In the literature, the detection "signal-on" or "signal-off" is usually associated with target binding-induced aptamer conformational change (Baldrich et al., 2006; Lai et al., 2007; Liu et al., 2010; Ma et al., 2013; Sánchez et al., 2006; Xiao et al., 2005a) and target binding-induced aptamer-complementary sequence dissociation/displacement strategies (Lu et al., 2008; Xiao et al., 2005b). This is due to the fact that aptamer-label or aptamer-complementary sequence-label after binding to its target promotes the approximation of the label on the electrode surface, thus increasing the current ("signal-on") or a distancing of the label from the 
A1
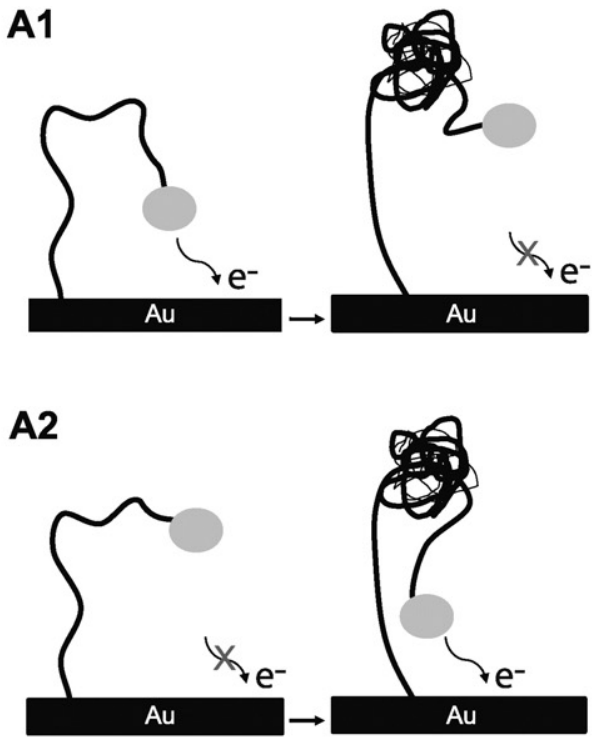

B1

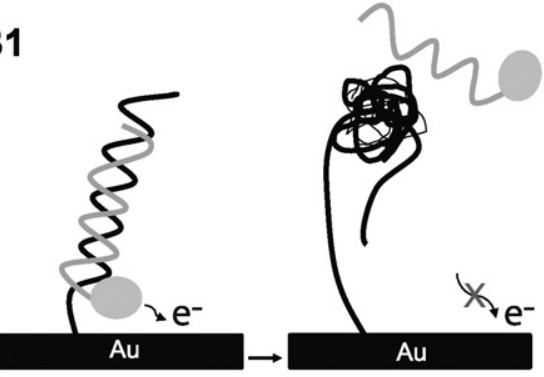

B2
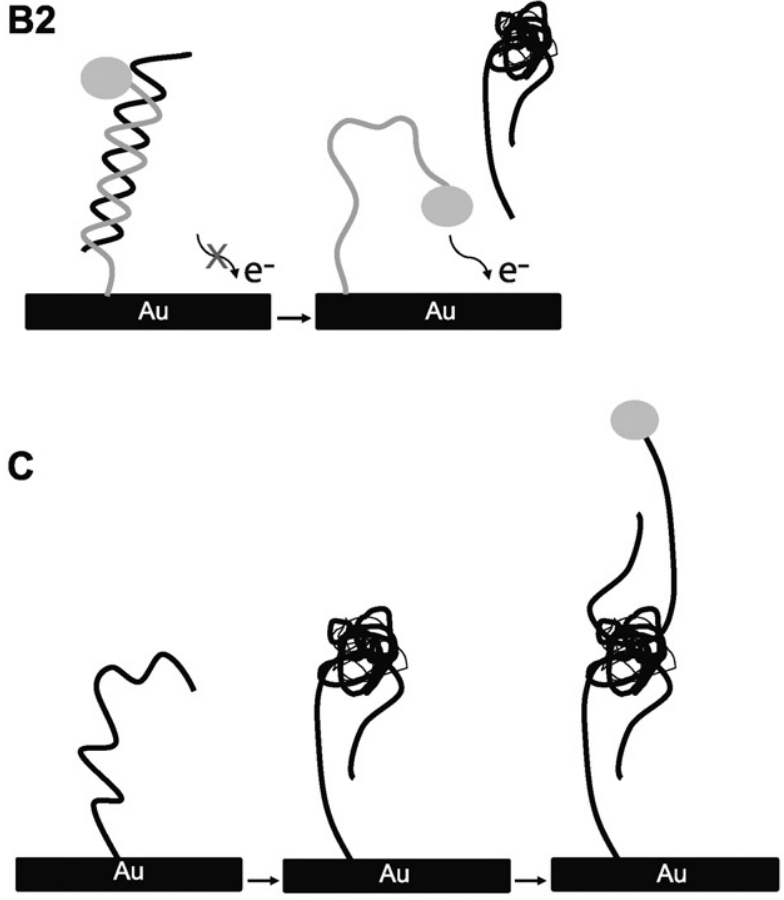

electrode surface, thus decreasing the current ("signal-off") (Sassolas et al., 2009). However, this classification "signal-on" and "signal-off", is also often employed in the sandwich assays (Centi et al., 2007, 2009; Zhang et al., 2007, 2009) or label-free aptasensors, when an increase or decrease of the signal is observed after the formation of the aptamer-target complex (Cheng et al., 2007; Degefa and Kwak, 2008; Meirinho et al., 2015; Rodríguez and Rivas, 2009).

Thrombin has been the most used protein to study electrochemical aptasensors. Its detection is crucial in many areas of biomedical research and diagnostic, as it is a multifunctional serine protease, whose concentration level in blood has high relevance in some pathologies (Wang et al., 2011). Therefore, the strategies used for the detection of thrombin can be a starting point for the development of similar strategies to detect many other cancer-related proteins (e.g. PDGF, OPN, VEGF, MUC1).

\subsection{Labelled electrochemical aptasensors}

In the labelled approaches, the bioreceptor can be labelled with a great variety of different redox compounds. These redox compounds can be covalently bound to the aptamer and modulate the electrochemical signal upon formation of the aptamer-target complex (Hayat and Marty, 2014; Palchetti and Mascini, 2012; Prieto-Simón et al., 2010; Sassolas et al., 2009). The aptamers can be labelled at both 3'- and 5'ends. At one end, for immobilization at the electrode surface and at the other end, the redox compounds for signal amplification (Strehlitz et al., 2008). The horseradish peroxidase (HRP), glucose oxidase (GOD) and alkaline phosphatase (AP) enzymes can also be used as redox compounds (Prieto-Simón et al., 2010). However, the most commonly used are ferrocene ( $\mathrm{Fc}$ ), $\mathrm{MB}$ and recently nanomaterials such as quantum dots (QDs) and nanoparticles (NPs), which present some advantages over the enzymes for biosensing assays (Hayat and Marty, 2014). Table 1 compiles some of the most relevant works that report the development of labelled electrochemical aptasensors using voltammetric techniques for the detection of specific proteins. The electrochemical cell, aptamer immobilization technique, redox compounds, design and detection assay type, detection limit, working range and applications are described for each example.

3.4.1. Aptasensors based on target binding-induced aptamer conformation

Xiao et al. (2005a) developed a labelled "signal-off" electrochemical aptasensor for the detection of thrombin in blood serum. Before binding the protein, the $3^{\prime}$-end MB-label aptamer is close to the electrode surface, thus allowing the transfer of electrons with the electrode surface due to the flexible structure of the aptamer. After thrombin binding, the aptamer forms a stable and rigid structure (G-quadruplex structure) and the MB-label is kept away from the electrode surface, the electron transfer is inhibited, resulting in a current decrease. The electrochemical measurements were performed by ACV and a low detection limit of

Fig. 4. Strategies to develop electrochemical aptasensors. A) Target binding-induced aptamer conformation change. A1) "Signal-off": the aptamer sequence remained unfolded, in the absence of target, and the redox moiety is close to the electrode surface: upon binding target, the aptamer changes the structure, displacing the redox moiety away from the gold electrode inhibiting the electron transfer process. A2) "Signal-on": inverse situation as the one referred as "signal-off", where upon aptamer-target binding, the aptamer's configuration changes displacing the redox moiety close to the electrode surface; B) target binding-induced aptamer-complementary sequence dissociation/ displacement. B1) "Signal-off": the aptamer immobilized onto the gold surface forms a double-stranded construct with a cDNA sequence labelled with redox moiety that is proximal to gold surface, allowing an efficient electron transfer between redox and gold surface, which is inhibited in the presence of the aptamer-target bound due to the release of the cDNA sequence. B2) "Signal-on": the labelled cDNA sequence immobilized onto the gold surface forms a double helix with an aptamer sequence, displacing the redox moiety away from the electrode; the unfolded cDNA sequence was obtained upon aptamer-target bound, displacing redox moiety close to the electrode surface promoting the electron transfer and signal increase; $C$ ) sandwich assays: two aptamers are used for target detection, one is immobilized onto the gold surface and the other is labelled with a redox moiety, resulting in dual binding sites for the target, allowing the formation of an aptamer-target-aptamer structure that promotes the electron transfer. 
Table 1

Labelled electrochemical aptasensors using voltammetric techniques for the detection of protein disease biomarkers.

\begin{tabular}{|c|c|c|c|c|c|c|c|c|c|c|}
\hline $\begin{array}{l}\text { Change } \\
\text { response }\end{array}$ & $\begin{array}{l}\text { Target/ } \\
\text { aptamers }\end{array}$ & $\begin{array}{l}\text { Electrochemical } \\
\text { cells }\end{array}$ & $\begin{array}{l}\text { Aptamer } \\
\text { immobilization }\end{array}$ & $\begin{array}{l}\text { Redox } \\
\text { compounds }\end{array}$ & $\begin{array}{l}\text { Electrochemical } \\
\text { technique }\end{array}$ & Assay type & $\begin{array}{l}\text { Detection } \\
\text { limit (LOD) }\end{array}$ & $\begin{array}{l}\text { Working/linear } \\
\text { range }\end{array}$ & Application & Reference \\
\hline \multirow[t]{5}{*}{ Signal-off } & $\begin{array}{l}\text { Thrombin } \\
\text { (DNA) }\end{array}$ & $\begin{array}{l}\text { WE: Au } \\
\text { RE: Ag/AgCl } \\
\text { AE: Pt wire }\end{array}$ & $\begin{array}{l}\text { 5'-End thiolated; } \\
\text { chemisorption }\end{array}$ & $\begin{array}{l}\text { 3'-End MB } \\
\text { label } \\
\text { aptamer }\end{array}$ & ACV & $\begin{array}{l}\text { Target } \\
\text { binding-induced } \\
\text { aptamer } \\
\text { conformational } \\
\text { change }\end{array}$ & $6.4 \mathrm{nM}$ & $50-768 \mathrm{nM}$ & $\begin{array}{l}\text { Thrombin } \\
\text { detection in } \\
\text { blood serum }\end{array}$ & $\begin{array}{l}\text { Xiao et al. } \\
(2005 a)\end{array}$ \\
\hline & $\begin{array}{l}\text { IFN- } \gamma \\
\text { (DNA) }\end{array}$ & $\begin{array}{l}\text { WE: Au; RE: } \\
\mathrm{Ag} / \mathrm{AgCl} \\
\text { AR: Pt wire }\end{array}$ & $\begin{array}{l}\text { 5'-Thiolated; } \\
\text { chemisorption }\end{array}$ & $\begin{array}{l}\text { 3'-End MB } \\
\text { label } \\
\text { aptamer }\end{array}$ & SWV & $\begin{array}{l}\text { Target } \\
\text { binding-induced } \\
\text { aptamer } \\
\text { conformational } \\
\text { change }\end{array}$ & $0.06 \mathrm{nM}$ & Up to $10 \mathrm{nM}$ & $\begin{array}{l}\text { IFN- } \gamma \\
\text { detection }\end{array}$ & $\begin{array}{l}\text { Liu et al. } \\
(2010)\end{array}$ \\
\hline & $\begin{array}{l}\text { MUC } 1 \\
\text { (DNA) }\end{array}$ & $\begin{array}{l}\text { WE: } \mathrm{Au} \\
\mathrm{RE}: \mathrm{Ag} / \mathrm{AgCl} \\
\mathrm{AE}: \mathrm{Pt}\end{array}$ & $\begin{array}{l}\text { 5'-Thiolated; } \\
\text { chemisorption }\end{array}$ & $\begin{array}{l}\text { 3'-End MB } \\
\text { label } \\
\text { aptamer }\end{array}$ & SWV & $\begin{array}{l}\text { Target } \\
\text { binding-induced } \\
\text { aptamer } \\
\text { conformational } \\
\text { change }\end{array}$ & $50 \mathrm{nM}$ & Up to $1.5 \mu \mathrm{M}$ & $\begin{array}{l}\text { MUC1 } \\
\text { detection }\end{array}$ & $\begin{array}{l}\text { Ma et al. } \\
(2013)\end{array}$ \\
\hline & VEGF & $\begin{array}{l}\text { WE: Au disk } \\
\text { RE: } \mathrm{Ag} / \mathrm{AgCl} \\
\mathrm{AE}: \mathrm{Pt}\end{array}$ & $\begin{array}{l}\text { 5'-Thiolated; } \\
\text { chemisorption }\end{array}$ & $\begin{array}{l}\text { 3'-End MB } \\
\text { label } \\
\text { aptamer }\end{array}$ & $\mathrm{ACV}$ & $\begin{array}{l}\text { Target } \\
\text { binding-induced } \\
\text { aptamer } \\
\text { conformational } \\
\text { change }\end{array}$ & $5 \mathrm{pM}$ & $50-150 \mathrm{pM}$ & $\begin{array}{l}\text { VEGF } \\
\text { detection in } \\
\text { human } \\
\text { whole blood }\end{array}$ & $\begin{array}{l}\text { Zhao et } \\
\text { al. } \\
\text { (2011b) }\end{array}$ \\
\hline & $\begin{array}{l}\text { TNF- } \alpha \\
\text { (RNA) }\end{array}$ & $\begin{array}{l}\text { WE: Au } \\
\text { RE: Ag/AgCl } \\
\text { AE: Pt wire }\end{array}$ & $\begin{array}{l}\text { 5'-Thiolated; } \\
\text { chemisorption }\end{array}$ & $\begin{array}{l}\text { 5'-End MB } \\
\text { label } \\
\text { aptamer }\end{array}$ & SWV & $\begin{array}{l}\text { Target } \\
\text { binding-induced } \\
\text { aptamer } \\
\text { conformational } \\
\text { change }\end{array}$ & $50 \mathrm{pM}$ & Up to $6 \mathrm{nM}$ & $\begin{array}{l}\text { TNF- } \alpha \\
\text { detection in } \\
\text { blood }\end{array}$ & $\begin{array}{l}\text { Liu et al. } \\
\text { (2013) }\end{array}$ \\
\hline \multirow[t]{6}{*}{ Signal-on } & $\begin{array}{l}\text { Thrombin } \\
\text { (DNA) }\end{array}$ & $\begin{array}{l}\text { WE: } \mathrm{Au} \\
\mathrm{RE}: \mathrm{Ag} / \mathrm{AgCl} \\
\mathrm{AE}: \mathrm{Pt}\end{array}$ & $\begin{array}{l}\text { 3'-End thiolated; } \\
\text { chemisorption }\end{array}$ & $\begin{array}{l}5^{\prime} \text {-End Fc } \\
\text { label } \\
\text { aptamer }\end{array}$ & DPV & $\begin{array}{l}\text { Target } \\
\text { binding-induced } \\
\text { aptamer } \\
\text { conformational } \\
\text { change }\end{array}$ & $0.5 \mathrm{nM}$ & $5-35 \mathrm{nM}$ & $\begin{array}{l}\text { Thrombin } \\
\text { detection }\end{array}$ & $\begin{array}{l}\text { Radi et al. } \\
\text { (2006) }\end{array}$ \\
\hline & $\begin{array}{l}\text { Thrombin } \\
\text { (DNA) }\end{array}$ & $\begin{array}{l}\text { WE: Au } \\
\text { RE: Ag/AgCl } \\
\text { AE: Pt wire }\end{array}$ & $\begin{array}{l}\text { 3'-End thiolated; } \\
\text { chemisorption }\end{array}$ & $\begin{array}{l}5^{\prime} \text {-End Fc } \\
\text { label } \\
\text { aptamer }\end{array}$ & SWV & $\begin{array}{l}\text { Target } \\
\text { binding-induced } \\
\text { aptamer } \\
\text { conformational } \\
\text { change }\end{array}$ & $1 \mathrm{nM}$ & $1-35 \mathrm{nM}$ & $\begin{array}{l}\text { Thrombin } \\
\text { detection }\end{array}$ & $\begin{array}{l}\text { Sánchez } \\
\text { et al. } \\
\text { (2006) }\end{array}$ \\
\hline & $\begin{array}{l}\text { Thrombin } \\
\text { (DNA) }\end{array}$ & $\begin{array}{l}\text { WE: carbon } \\
\text { RE: Ag } \\
\text { AE: carbon }\end{array}$ & $\begin{array}{l}\text { Two 5'-end } \\
\text { biotinylated; } \\
\text { streptavidin-biotin } \\
\text { interaction. }\end{array}$ & $\begin{array}{l}\text { AP } \\
\text { conjugated } \\
\text { secondary } \\
\text { aptamer }\end{array}$ & DPV & $\begin{array}{l}\text { Sandwich } \\
\text { (APT1/THR/APT2) }\end{array}$ & $0.5 \mathrm{nM}$ & ND & $\begin{array}{l}\text { Thrombin } \\
\text { detection in } \\
\text { serum }\end{array}$ & $\begin{array}{l}\text { Centi et } \\
\text { al. (2007) }\end{array}$ \\
\hline & PDGF-BB & $\begin{array}{l}\text { WE: Au } \\
\text { RE: Ag/AgCl } \\
\text { AE: Pt wire }\end{array}$ & $\begin{array}{l}\text { 5'-End thiolated; } \\
\text { chemisorption }\end{array}$ & $\begin{array}{l}\text { 3'-End MB } \\
\text { label } \\
\text { aptamer }\end{array}$ & $\mathrm{ACV}$ & $\begin{array}{l}\text { Target } \\
\text { binding-induced } \\
\text { aptamer } \\
\text { conformational } \\
\text { change }\end{array}$ & $\begin{array}{l}1 \mathrm{nM} \text { (blood } \\
\text { serum); } 50 \\
\mathrm{pM}(\text { diluted } \\
\text { serum) }\end{array}$ & ND & $\begin{array}{l}\text { PDGF } \\
\text { detection in } \\
\text { blood serum }\end{array}$ & $\begin{array}{l}\text { Lai et al. } \\
\text { (2007) }\end{array}$ \\
\hline & $\begin{array}{l}\text { PDGF-BB } \\
\text { (DNA) }\end{array}$ & $\begin{array}{l}\text { WE: Au } \\
\text { RE: SCE } \\
\text { AE: Pt }\end{array}$ & $\begin{array}{l}5^{\prime} \text {-End thiolated; } \\
\text { chemisorption }\end{array}$ & $\begin{array}{l}\text { 3'-End Fc } \\
\text { label } \\
\text { attached } \\
\text { secondary } \\
\text { aptamer }\end{array}$ & DPV & $\begin{array}{l}\text { Sandwich } \\
\text { (APT1/THR/APT2) }\end{array}$ & $39.37 \mathrm{fM}$ & $\begin{array}{l}39.37 \\
\mathrm{fM}-39.37 \mathrm{pM}\end{array}$ & $\begin{array}{l}\text { PDGF-BB } \\
\text { detection }\end{array}$ & $\begin{array}{l}\text { Zhang et } \\
\text { al. (2007) }\end{array}$ \\
\hline & $\begin{array}{l}\text { C-reactive } \\
\text { protein } \\
\text { (CRP) } \\
\text { (RNA) }\end{array}$ & $\begin{array}{l}\text { WE: carbon } \\
\text { RE: Ag } \\
\text { AE: carbon }\end{array}$ & $\begin{array}{l}5^{\prime} \text {-End } \\
\text { biotinylated; } \\
\text { streptavidin-biotin } \\
\text { interaction }\end{array}$ & $\begin{array}{l}\text { AP } \\
\text { conjugated } \\
\text { biotinylated } \\
\text { antibody }\end{array}$ & DPV & $\begin{array}{l}\text { Sandwich } \\
\text { (APT/CRP/antibody) }\end{array}$ & $\begin{array}{l}2 \mathrm{nM} \text { (free } \\
\text { serum) }\end{array}$ & $1 \mathrm{nM}-0.5 \mu \mathrm{M}$ & $\begin{array}{l}\text { CRP } \\
\text { detection in } \\
\text { free serum } \\
\text { and serum } \\
\text { samples }\end{array}$ & $\begin{array}{l}\text { Centi et } \\
\text { al. (2009) }\end{array}$ \\
\hline
\end{tabular}

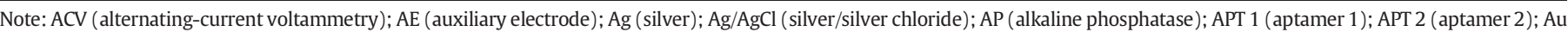

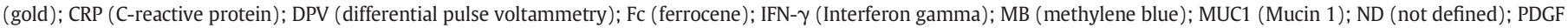

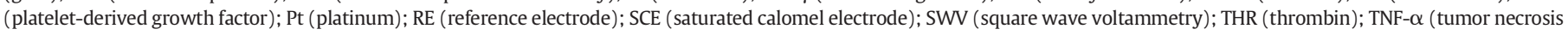
factor alpha); VEGF (vascular endothelial growth factor); WE (working electrode); units converted to Molar taking into account the molecular weight 25.4 kDa (PDGF-BB).

$6.4 \mathrm{nM}$ was reported, thus highlighting the potential of these approaches for diagnosis purposes. Likewise, Liu et al. (2010) developed a label "signal-off" aptasensor for the detection of interferon gamma (IFN- $\gamma$ ). The aptamer against IFN- $\gamma$ was 5 '-end thiolated, conjugated with 3'-MB-label and immobilized on a gold electrode surface. The IFN- $\gamma$ binding induced an aptamer conformation change, increased the distance of MB-label from the electrode surface and led to a decrease of the electron transfer and consequently of the current. The SWV was used to quantify the current decrease and a very low detection limit was achieved. This labelled "signal-off" electrochemical aptasensor proved to be sensitive and specific to IFN- $\gamma$ in the presence of overabundant serum protein. The authors used the same strategy (Liu et al.,
2013) for the detection of TNF- $\alpha$ also using a RNA aptamer modified with the thiol group and MB-label for immobilization and amplification of signal, respectively. Similarly, in this case the aptasensor detected the target protein (TNF- $\alpha$ ) in blood samples with good sensitivity. Ma et al. (2013) developed a labelled "signal-off" electrochemical aptasensor towards another protein biomarker, MUC1, which is a glycoprotein implicated in some cancers, as breast cancer. The thiolated DNA aptamer was immobilized onto a gold electrode surface and the other aptamer end was labelled with MB to enable the electrochemical measurements. In the absence of MUC1, one hairpin structure was formed and the electrode transfer between MB-label and the gold electrode was facilitated. Upon MUC1 binding, a conformational change of the aptamer was 
induced, the MB-label was removed from the electrode surface and a decrease in the current was observed. This electrochemical aptasensor showed good specificity in the presence of other proteins and could be seen as a very promising tool in clinical applications. Using the same type of labels (thiol- and MB-modified DNA aptamer), Zhao et al. (2011b) developed an aptasensor for the detection VEGF in blood serum and whole blood. Upon VEGF binding, the partially unfolded aptamer formed a conformational restrict stem-loop structure. This conformational change forces the MB label to be in the close proximity of the electrode, thus resulting in a significant increase of the electron transfer and current signal. An outstanding detection limit of $5 \mathrm{pM}$ $(190 \mathrm{pg} / \mathrm{mL}$ ) was achieved in $50 \%$ of blood serum. In the same work, a gold-plated screen-printed carbon electrode was tested showing a similar performance.

Sánchez et al. (2006) and Radi et al. (2006) implemented the target binding-induced aptamer conformation principle to develop "signalon" electrochemical aptasensors to detect thrombin. The aptamers were modified with Fc and SWV or DPV were used for the electrochemical measurements, respectively. In both reports the detection limits obtained were very low (lower than the signal-off reported by Xiao et al. (2005a)), again suggesting the potential of these biosensors. Using the same strategy, Lai et al. (2007) reported a labelled "signal-on" electrochemical aptasensor for the detection of platelet-derived growth factor B-chain (PDGF-BB) in clinical samples. The aptasensor was constructed by immobilizing a MB-label aptamer onto a gold electrode surface through a thiol group. In the absence of PDGF-BB, the MB-label is far away from the electrode surface. Upon PDGF-BB binding, the aptamer forms a stable structure holding the MB-label close to the electrode surface, improving the electron transfer. The ACV was used to monitor the changes at the electrode surface and a detection limit of $1 \mathrm{nM}$ was obtained in blood serum and of $50 \mathrm{pM}$ in serum 2-fold diluted with buffer. This aptasensor showed excellent stability in real samples and could be regenerated by disrupting aptamer-PDGF-BB.

\subsubsection{Aptasensors based on sandwich design}

Apart from the target binding-induced aptamer conformational change, other designs have been explored to develop electrochemical aptasensors. The sandwich format presents an increased sensitivity and selectivity concerning the detection of the target molecule. However, two conditions are required for this sensor arrangement, namely (a) the target must have two independent binding sites (epitopes) to which two different ligands (aptamers) may bind the target molecule without affecting the binding of other targets; and (b) two or more aptamers are selected against the target (Han et al., 2010; Palchetti and Mascini, 2012).

In this type of arrangement, generally, one aptamer is immobilized onto the electrode surface, while the other is used as a label for signal amplification. Very few target molecules (thrombin and PDGF) have two binding sites and two or more isolated aptamers, which limits the use of this type of sensor format. However, this limitation can be circumvented through the use of the two following formats for the design of an aptasensor, namely the aptamer-protein-aptamer (using the same aptamer) and aptamer-protein-antibody (Han et al., 2010; Palchetti and Mascini, 2012; Taleat et al., 2014). Commonly, the secondary ligands can be labelled with different redox labels such as MB, Fc, nanomaterials (e.g. NPs) or enzymes (e.g. HRP or AP). Another disadvantage of this format is the time consuming steps of incubation (Palchetti and Mascini, 2012).

Some works have reported the use of the sandwich-format aptasensor for the detection of different proteins, namely thrombin (Centi et al., 2007; Ding et al., 2010; Kang et al., 2008; Zhao et al., 2011a), C-reactive protein (CRP) (Centi et al., 2009) and PDGF (Wang et al., 2009; Zhang et al., 2007, 2009). Centi et al. (2007) developed a labelled "signal-on" electrochemical aptasensor for the detection of thrombin in complex matrices using the sandwich assay with magnetic particles as solid supports. Two biotinylated aptamers against thrombin were used for the aptasensor design. A biotinylated aptamer was captured onto streptavidin-coated magnetic beads and the resulting aptamer-modified magnetic beads were incubated with thrombin. Upon binding with thrombin, a biotinylated secondary aptamer was added, which was ready to bind in a further step to a streptavidin-AP conjugate. A detection limit of $0.5 \mathrm{nM}$ was obtained which is much lower than the values reported by the other authors previously mentioned that developed aptasensors based on target binding-induced aptamer conformational changes (Lai et al., 2007; Ma et al., 2013; Sánchez et al., 2006; Xiao et al., 2005a). These authors used the same strategy for detecting the CRP protein. However, in this case a biotinylated aptamer with affinity for CRP immobilized onto streptavidin magnetic beads (capture probe) and a biotinylated monoclonal antibody anti-CRP conjugated with alkaline phosphatase (AP) (detection probe) were used. Again very low detection limits $(2 \mathrm{nM})$ in serum samples were obtained (Centi et al., 2009). A similar sandwich strategy was designed by Zhang et al. $(2007,2009)$ to detect the proteins PDGF-BB and PDGF, respectively. In these works, the detection of the protein targets was based on the proximity-dependent surface hybridization assay. Two aptamers that recognize different sites of the protein target were used. The 5'-end of both aptamers was coupled to a short complementary sequence. The recognition of the protein by the pair of aptamers enabled the hybridization between the complementary sequences of both aptamer probes, which promotes the proximity of the two tail sequence of both aptamers and the cooperative annealing of the aptamer-proteinaptamer complex on capture probes immobilized on the electrode. As a result, an increase of the redox signal by proximity of Fc-label attached to the secondary aptamer with the gold electrode was promoted. Outstanding detection limits for PDGF-BB (1 pg/mL) and PDGF (0.1 ng/ $\mathrm{mL}$ ) were obtained.

\subsection{Label-free electrochemical aptasensors}

In the label-free approaches, the bioreceptor is not labelled with redox compounds (Prieto-Simón et al., 2010; Sassolas et al., 2009; Strehlitz et al., 2008). The aptamers are immobilized on the electrode surface and the target-aptamer interaction is detected by electrochemical techniques (such as voltammetry and electrochemical impedance spectroscopy (EIS)) through electroactive molecules such as ferricyanide and ruthenium complexes $\left(\left[\mathrm{Fe}(\mathrm{CN})_{6}\right]^{3-/ 4-} \text { and } \mathrm{Ru}\left(\mathrm{NH}_{3}\right)_{6}\right]^{3+}$, respectively) that can be electrostatically associated or can diffusively interact (attraction/repulsion) with the aptamers (Prieto-Simón et al., 2010). However, in some cases labelled aptamer-complementary sequences or MB-intercalate can be used in these approaches (Prieto-Simón et al., 2010; Sassolas et al., 2009; Strehlitz et al., 2008) and the changes on the electrode surface can result in target binding-induced aptamer-complementary sequence dissociation/displacement or target binding-induced aptamer conformational change, respectively. Table 2 summarizes some relevant studies on electrochemical aptasensors using voltammetric techniques that have been developed for specific protein detection using label-free detection.

\subsubsection{Aptasensors based on target binding-induced aptamer conformation}

Bang et al. (2005) developed a signal-off electrochemical aptasensor for the detection of thrombin using the target binding-induced aptamer conformation principle. In the construction of the aptasensor, a modified aptamer with MB-label intercalated into the sequence was used, and this aptamer was covalently attached onto the gold electrode. The aptamer-thrombin interaction led to the change of the aptamer conformation and consequently to a decrease in the current intensity. This simple method allowed the detection of thrombin with a detection limit of $11 \mathrm{nM}$, which is similar to some of the examples using different approaches abovementioned. In the same year, Hianik et al. (2005) developed a signal-on aptasensor also to detect thrombin. The avidin-biotin interaction was used to immobilize the aptamers onto the gold electrode surface. Thrombin was detected based on the change of 
Table 2

Label-free electrochemical aptasensors using voltammetric techniques for the detection of protein disease biomarkers.

\begin{tabular}{|c|c|c|c|c|c|c|c|c|c|c|}
\hline $\begin{array}{l}\text { Change } \\
\text { response }\end{array}$ & $\begin{array}{l}\text { Target/ } \\
\text { aptamer }\end{array}$ & $\begin{array}{l}\text { Electrochemical } \\
\text { cells }\end{array}$ & $\begin{array}{l}\text { Aptamers } \\
\text { immobilization }\end{array}$ & $\begin{array}{l}\text { Redox } \\
\text { compounds }\end{array}$ & $\begin{array}{l}\text { Electrochemical } \\
\text { technique }\end{array}$ & Assay type & $\begin{array}{l}\text { Detection } \\
\text { limit (LOD) }\end{array}$ & $\begin{array}{l}\text { Working/linear } \\
\text { range }\end{array}$ & Application & Reference \\
\hline \multirow[t]{4}{*}{ Signal-off } & $\begin{array}{l}\text { Thrombin } \\
\text { (DNA) }\end{array}$ & $\begin{array}{l}\text { WE: Au } \\
\text { RE: Ag/AgCl } \\
\text { AE: Pt wire }\end{array}$ & $\begin{array}{l}\text { 5'-End amine; } \\
\text { covalent } \\
\text { attachment }\end{array}$ & $\begin{array}{l}\text { MB-intercalated } \\
\text { label }\end{array}$ & DPV & $\begin{array}{l}\text { Target } \\
\text { binding-induced } \\
\text { aptamer } \\
\text { conformational } \\
\text { change }\end{array}$ & $11 \mathrm{nM}$ & Up to $50.8 \mathrm{nM}$ & $\begin{array}{l}\text { Thrombin } \\
\text { detection }\end{array}$ & $\begin{array}{l}\text { Bang et } \\
\text { al. (2005) }\end{array}$ \\
\hline & $\begin{array}{l}\text { Thrombin } \\
\text { (DNA) }\end{array}$ & $\begin{array}{l}\text { WE: Au } \\
\text { RE: Ag/AgCl } \\
\text { AE: Pt wire }\end{array}$ & $\begin{array}{l}5^{\prime} \text {-End thiolated; } \\
\text { chemisorption }\end{array}$ & $\begin{array}{l}\text { Fc-short } \\
\text { labelled cDNA } \\
\text { sequence }\end{array}$ & DPV & $\begin{array}{l}\text { Target } \\
\text { binding-induced } \\
\text { aptamer-cDNA } \\
\text { sequence } \\
\text { dissociation }\end{array}$ & $2 \mathrm{nM}$ & Up to $10 \mathrm{nM}$ & $\begin{array}{l}\text { Thrombin } \\
\text { detection }\end{array}$ & $\begin{array}{l}\text { Lu et al. } \\
\text { (2008) }\end{array}$ \\
\hline & $\begin{array}{l}\text { PDGF } \\
\text { (DNA) }\end{array}$ & $\begin{array}{l}\text { WE: Au } \\
\text { RE: MSE } \\
\text { AE: Pt wire }\end{array}$ & $\begin{array}{l}\text { 5'-Thiolated; } \\
\text { chemisorption }\end{array}$ & {$\left[\mathrm{Fe}(\mathrm{CN})_{6}\right]^{3-/ 4-}$} & DPV & $\begin{array}{l}\text { Target } \\
\text { binding-induced } \\
\text { aptamer } \\
\text { conformational } \\
\text { change }\end{array}$ & ND & $1-40 \mathrm{nM}$ & $\begin{array}{l}\text { PDGF } \\
\text { detection }\end{array}$ & $\begin{array}{l}\text { Degefa } \\
\text { and Kwak } \\
(2008)\end{array}$ \\
\hline & $\begin{array}{l}\text { Osteopontin } \\
\text { (RNA) }\end{array}$ & $\begin{array}{l}\text { WE: Au; } \\
\text { RE: Ag } \\
\text { AE: } \mathrm{Au}\end{array}$ & $\begin{array}{l}\text { 5'-End-biotinylated; } \\
\text { streptavidin-biotin } \\
\text { interaction }\end{array}$ & {$\left[\mathrm{Fe}(\mathrm{CN})_{6}\right]^{3-/ 4-}$} & $\mathrm{CV}$ & $\begin{array}{l}\text { Target } \\
\text { binding-induced } \\
\text { aptamer } \\
\text { conformational } \\
\text { change }\end{array}$ & $3.7 \mathrm{nM}$ & $25-2402 \mathrm{nM}$ & $\begin{array}{l}\text { Osteopontin } \\
\text { detection }\end{array}$ & $\begin{array}{l}\text { Meirinho } \\
\text { et al. } \\
(2015)\end{array}$ \\
\hline \multirow[t]{3}{*}{ Signal-on } & $\begin{array}{l}\text { Thrombin } \\
\text { (DNA) }\end{array}$ & WE: Au & $\begin{array}{l}\text { 5'-End thiolated; } \\
\text { chemisorption }\end{array}$ & $\begin{array}{l}\text { MB-attached } \\
\text { partially cDNA } \\
\text { sequence }\end{array}$ & $\mathrm{ACV}$ & $\begin{array}{l}\text { Target } \\
\text { binding-induced } \\
\text { aptamer-cDNA } \\
\text { sequence } \\
\text { displacement }\end{array}$ & $3 \mathrm{nM}$ & Up to $80 \mathrm{nM}$ & $\begin{array}{l}\text { Thrombin } \\
\text { detection }\end{array}$ & $\begin{array}{l}\text { Xiao et al. } \\
\text { (2005b) }\end{array}$ \\
\hline & $\begin{array}{l}\text { Thrombin } \\
\text { (DNA) }\end{array}$ & $\begin{array}{l}\text { WE: Au } \\
\text { RE: Ag/AgCl } \\
\text { AE: Pt wire }\end{array}$ & $\begin{array}{l}\text { 3'-End biotinylated; } \\
\text { streptavidin-biotin } \\
\text { interaction }\end{array}$ & $\begin{array}{l}\text { MB-intercalated } \\
\text { label }\end{array}$ & DPV & $\begin{array}{l}\text { Target } \\
\text { binding-induced } \\
\text { aptamer } \\
\text { conformational } \\
\text { change }\end{array}$ & $10 \mathrm{nM}$ & ND & $\begin{array}{l}\text { Thrombin } \\
\text { detection }\end{array}$ & $\begin{array}{l}\text { Hianik et } \\
\text { al. (2005) }\end{array}$ \\
\hline & $\begin{array}{l}\text { VEGF and } \\
\text { MUC1 } \\
\text { (DNA/DNA) }\end{array}$ & $\begin{array}{l}\text { WE: Au } \\
\text { RE: SCE } \\
\text { AE: Pt wire }\end{array}$ & $\begin{array}{l}5 \text { '-Thiolated cDNA } \\
\text { sequence } \\
\text { Chemisorption }\end{array}$ & $\begin{array}{l}\text { Fc-labelled } \\
\text { cDNA sequence }\end{array}$ & SWV & $\begin{array}{l}\text { Hybridization } \\
\text { reaction between } \\
\text { cDNA sequence } \\
\text { and two aptamers }\end{array}$ & $\begin{array}{l}\text { MUC1: } 0.33 \\
\text { nM } \\
\text { VEGF: ND }\end{array}$ & $1-20 \mathrm{nM}$ & $\begin{array}{l}\text { VEGF and } \\
\text { MUC1 } \\
\text { detection }\end{array}$ & $\begin{array}{l}\text { Zhao et } \\
\text { al. (2012) }\end{array}$ \\
\hline
\end{tabular}

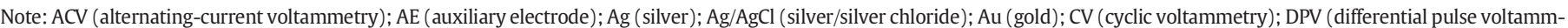

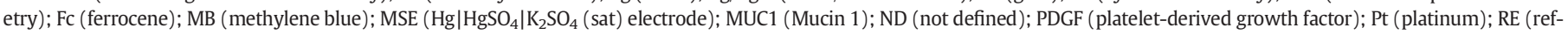
erence electrode); SCE (saturated calomel electrode); SWV (square wave voltammetry); VEGF (vascular endothelial growth factor); WE (working electrode).

current intensity upon binding of the thrombin to the electrode covered with DNA aptamer. The detection limit obtained with this aptasensor was better than the previous example. Degefa and Kwak (2008) reported a label-free approach for detecting the PDGF cancer-related protein using $\left[\mathrm{Fe}(\mathrm{CN})_{6}\right]^{3-/ 4-}$ as a redox probe. The DNA aptamer against PDGF was self-assembled in a monolayer onto the gold surface which, in the absence of the PDGF, showed a dynamic state and efficient electron transfer between the redox probe and the electrode surface. After PDGF binding-induced aptamer conformation change, the electron transfer was significantly affected and a linear decrease of the peak current with the protein concentration was observed. We used a similar strategy to develop an aptasensor for the detection of OPN, a potential biomarker for breast cancer (Meirinho et al., 2015). An RNA aptamer was immobilized on a streptavidin-modified gold surface through the streptavidin-biotin interaction. After binding the OPN, the current decrease was measured by $\mathrm{CV}$ in the presence of $\left[\mathrm{Fe}(\mathrm{CN})_{6}\right]^{3-14-}$ that is the redox probe. The "signal-off" electrochemical aptasensor showed sensitivity and selectivity towards OPN (detection limit of $3.7 \mathrm{nM}$ ) and was able to detect OPN in the presence of other interfering proteins, with the exception of thrombin. The very low detection limit obtained suggests the great potential of this aptasensor since OPN is usually present in low concentrations in biological fluids.

\subsubsection{Aptasensors based on target binding-induced aptamer dissociation/} displacement

Another strategy for the design of electrochemical aptasensors is based on the target-induced aptamer dissociation/displacement. This strategy is grounded mainly in the strong affinity of the label-free aptamer to its specific target with a labelled aptamer-complementary sequence (Han et al., 2010). Upon binding of the target-aptamer, the dissociation/displacement of the complementary sequences of the aptamer occurs, which leads to the change of detectable signals. This strategy was used to detect thrombin (Lu et al., 2008; Xiao et al., 2005b). Xiao et al. (2005b) developed a "signal-on" aptasensor using an aptamer immobilized onto a gold electrode and then hybridized with a partially complementary DNA sequence labelled with MB. Upon thrombin binding, the aptamer adopted a G-quadruplex conformation and the labelled aptamer-cDNA sequence pushed MB closer to the gold electrode surface, thus giving rise to a detectable current that could be measured by ACV. This aptasensor allowed the detection of thrombin in a linear concentration range up to $80 \mathrm{nM}$ with a detection limit of $3 \mathrm{nM}$, which is quite good as compared to the previous examples. Lu et al. (2008) developed a "signal-off" aptasensor for the same protein, using a Fc-labelled short aptamer-complementary DNA sequence to form dsDNA duplex with the aptamer immobilized on a gold electrode. The target binding led to the dissociation of the label-sequence that was followed by a decrease in the DPV current signal due to the distance between the Fc-label and the gold electrode. The aptasensor was found to be reusable and highly specific with a detection limit of $2 \mathrm{nM}$.

Recently, Zhao et al. (2012) reported a label-free electrochemical aptasensor for the simultaneous detection of two tumor markers, MUC1 and VEGF that are associated with a poor prognosis and poor survival of the breast cancer patients. In this aptasensor, the Fc-labelled aptamer-complementary DNA sequence was immobilized onto the gold disk electrode that hybridizes with both MUC1 and VEGF aptamers to form a long double strand blocking the electrochemical signal. In the presence of the two tumor markers, the hybridization reaction between 
the cDNA and the aptamers was inhibited and, Fc-cDNA was close to the electrode surface, being the increase in the current detected by SWV. This simple "signal-on" electrochemical aptasensor allowed the detection of the two markers and most importantly the discrimination of their co-existence.

\subsection{Use of nanomaterials in electrochemical aptasensors}

In order to achieve highly sensitive electrochemical aptasensors, several nanomaterials have been explored for the immobilization of aptamers onto electrode surfaces and for signal transduction. Metal nanoparticles (e.g. AuPNs, AgNPs, PtNPs), silica nanoparticles (Si NPs), QDs, magnetic nanoparticles (MNPs), carbon nanotubes (CNTs), graphene (GNs) and their nanocomposites have been used for the development of electrochemical biosensors (Bai et al., 2012; Cao et al., 2014; Chen et al., 2015; Deng et al., 2013b; Hu et al., 2014; Jo et al., 2015; Li et al., 2011b; Ravalli et al., 2015; Wang et al., 2011; Zhao et al., 2011a) These nanomaterials have unique physical and chemical properties and can be used in several electrode surfaces such as GCE (Ding et al., 2010; Li et al., 2011b) and SPE (Suprun et al., 2008) in a variety of applications. For electrochemical applications, these nanomaterials allowed an easy functionalization of the electrode surfaces, namely an increase of the surface area for the aptamers attachment onto the electrode surfaces, therefore facilitating the access of the target molecule to these aptamers, and acting as electrochemical labels by increasing the signal amplification or electron-transfer mediators (Citartan et al., 2012; Erdem et al., 2009; Hernandez and Ozalp, 2012; Palchetti and Mascini, 2012; Vidotti et al., 2011; Vikesland and Wigginton, 2010; Wang et al., 2015). Taking into account these advantages, the use of nanomaterials in the development of aptasensors will lead to an increase in the sensitivity, i.e. in the detection of low levels of protein biomarkers. However, this strategy can also enclose some disadvantages, such as complicated procedures, increased expenses, decreased reproducibility and quantification, especially when the use of complex samples is envisaged (Palchetti and Mascini, 2012). Table 3 summarizes some studies that used nanomaterials to develop electrochemical aptasensors using voltammetric techniques for specific protein detection and disease diagnosis. It is important to mention that the most recent reports on electrochemical aptasensors involve the use of nanomaterials for their improvement, thus highlighting the relevance of these approaches.

The use of AuNPs in aptasensors for the amplification of the signal and as a target recognition element has been described by Ding et al. (2010). The authors used cadmium sulfide-quantum dots (CdS-QDs) to modify the surface of AuNPs for the detection of thrombin. This strategy greatly improved the aptasensor sensitivity comparing to other examples previously described, mainly due to the signal amplification. Wang et al. (2011) also reported a multi-amplification aptasensor to detect thrombin based on graphene matrix. The fabrication of this sandwich electrochemical aptasensor used: (i) hollow CoPt bimetal alloy nanoparticles ( $\mathrm{HCoPt}$ ) and conjugated reduced graphene oxide sheets (RGs), which allowed loading several redox probes as thionine (Thi), HRP and secondary aptamer-2 (HCoPt-RGs-Thi-HRP) and (ii) GCE surface modified with chitosan-hollow CoPt alloy nanoparticle (CsHcoPt) film activated with glutaraldehyde (GA) for the immobilization of aptamer-1. This aptasensor, using CV and DPV techniques, presented a low detection limit and a good specificity for thrombin, thus suggesting that these approaches improve the aptasensors performance, demonstrating the promising application of graphene for other protein detection and disease diagnosis. Zhao et al. (2011a) reported another example for thrombin detection based on the amplification of aptamer-AuNPs-HRP conjugates. The aptamer- 1 was immobilized into core/shell iron oxide/gold magnetic nanoparticles $\left(\mathrm{Fe}_{3} \mathrm{O}_{4}\right.$-AuMNPs) (capture probe) and the aptamer-2 was coupled with AuNPs and HRP for signal amplification (detection probe). The proposed sandwich electrochemical aptasensor provided remarkable signal amplification, due

Table 3

Electrochemical aptasensors using voltammetric techniques for the detection of protein disease biomarkers using nanomaterials.

\begin{tabular}{|c|c|c|c|c|c|c|}
\hline Target/aptamers & Nanomaterials & $\begin{array}{l}\text { Electrochemical } \\
\text { technique }\end{array}$ & $\begin{array}{l}\text { Detection limit } \\
\text { (LOD) }\end{array}$ & Working range & Application & Reference \\
\hline Thrombin (DNA) & NPs & DPV & $0.55 \mathrm{fM}$ & $1.0-10 \mathrm{fM}$ & $\begin{array}{l}\text { Thrombin detection in } \\
\text { real samples }\end{array}$ & Ding et al. (2010) \\
\hline Thrombin (DNA) & AuMNPs and AuNPs & DPV & $30 \mathrm{fM}$ & $0.1-60 \mathrm{pM}$ & Thrombin detection & $\begin{array}{l}\text { Zhao et al. } \\
\text { (2011a) }\end{array}$ \\
\hline Thrombin (DNA) & CdSe - QDs & DPV & $2.14 \mathrm{nM}$ & $\begin{array}{l}80.21-347.59 \mathrm{nM} \text { and } \\
37.4-828.88 \mathrm{nM}\end{array}$ & Thrombin detection & Li et al. (2011b) \\
\hline Thrombin (DNA) & GNs and AuNPs & DPV & $0.2 \mathrm{pM}$ & $1 \times 10^{-3}-40 \mathrm{nM}$ & Thrombin detection & Yuan et al. (2011) \\
\hline Thrombin (DNA) & GNs and NPs & DPV & $3.4 \times 10^{-13} \mathrm{M}$ & $1.0 \times 10^{-12}-5.0 \times 10^{-8} \mathrm{M}$ & Thrombin detection & $\begin{array}{l}\text { Wang et al. } \\
(2011)\end{array}$ \\
\hline Thrombin (DNA) & GNs-CS & DPV & $0.45 \times 10^{-3} \mathrm{pM}$ & $1 \times 10^{-6}-1 \times 10^{-4} \mathrm{nM}$ & Thrombin detection & $\begin{array}{l}\text { Wang et al. } \\
\text { (2012) }\end{array}$ \\
\hline PDGF (DNA) & AuNPs & $\mathrm{CV}$ & $\begin{array}{l}1 \times 10^{-14} \mathrm{M} \\
\text { (diluted) } \\
1 \times 10^{-12} \mathrm{M} \\
\text { (undiluted) }\end{array}$ & n.d. & $\begin{array}{l}\text { PDGF detection in } \\
\text { purified samples } \\
\text { and undiluted } \\
\text { blood serum }\end{array}$ & $\begin{array}{l}\text { Wang et al. } \\
\text { (2009) }\end{array}$ \\
\hline $\begin{array}{l}\text { PDGF and thrombin } \\
\text { (DNA/DNA) }\end{array}$ & $\begin{array}{l}\text { rGS-PtNPs and } \\
\text { AuNPs-SWCNTs }\end{array}$ & DPV & $\begin{array}{l}8 \mathrm{pM} \text { (PDGF) } \\
11 \mathrm{pM} \text { (thrombin) }\end{array}$ & $\begin{array}{l}0.01-35 \mathrm{nM}(\mathrm{PDGF}) \\
0.02-45 \mathrm{nM} \text { thrombin }\end{array}$ & $\begin{array}{l}\text { PDGF and thrombin } \\
\text { detection }\end{array}$ & Bai et al. (2012) \\
\hline PDGF (DNA) & GNs and AuNPs & $\mathrm{CV}$ & $1.7 \mathrm{pM}$ & $5 \times 10^{-3}-60 \mathrm{nM}$ & PDGF detection & $\begin{array}{l}\text { Deng et al. } \\
\text { (2013b) }\end{array}$ \\
\hline MUC1 (DNA) & AuNPs and MWCNTs & DPV & $2.2 \mathrm{nM}$ & 8.8-353.3 nM & MUC1 detection & Hu et al. (2014) \\
\hline MUC1 (DNA) & AuNPs and MWCNTs & DPV & $1 \mathrm{pM}$ & $1-100 \mathrm{nM}$ & MUC1 detection & Chen et al. (2015) \\
\hline Osteopontin (RNA) & $\mathrm{CB}[7]$ and AuNPs & SWV & $164.62 \mathrm{pM}$ & $769.23 \mathrm{pM}-7.69 \mathrm{nM}$ & Osteopontin detection & Cao et al. (2014) \\
\hline VEGF (DNA) & AuNPs & DPV & $30 \mathrm{nM}$ & $0-250 \mathrm{nM}$ & VEGF detection & $\begin{array}{l}\text { Ravalli et al. } \\
(2015)\end{array}$ \\
\hline VEGF (DNA) & BSA-AuNCs & DPV & $0.32 \mathrm{pM}$ & $1-120 \mathrm{pM}$ & VEGF detection & $\begin{array}{l}\text { Shamsipur et al. } \\
\text { (2015) }\end{array}$ \\
\hline
\end{tabular}

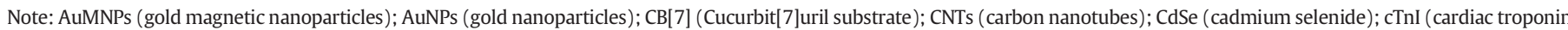

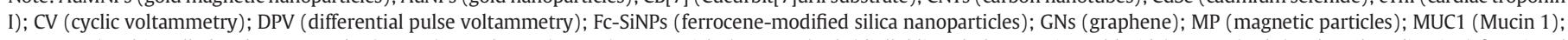

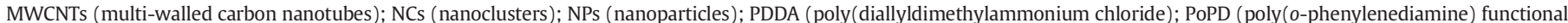

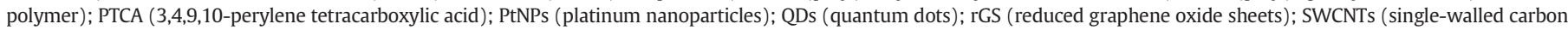

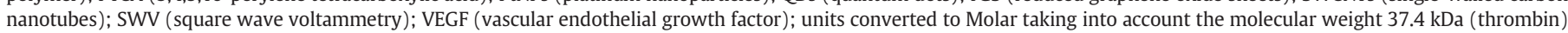
and $65 \mathrm{kDa}$ (osteopontin). 
to the AuNPs and catalytic reaction of HRP, showing a detection limit of $30 \mathrm{fM}$, obtained by applying DPV technique.

This recent use of nanomaterials also enabled the development of some aptasensors for the electrochemical detection of proteins associated with breast cancer. Cao et al. (2014) reported a label-free electrochemical aptasensor for OPN using a strategy that does not require the aptamers immobilization on the electrode surface. This strategy includes: (i) the electrode functionalization using AuNPs and cucurbit[7]uril which, allows an efficient capture of MB tag and (ii) the OPN target binding to RNA aptamer (R3-OPN) (Mi et al., 2009) by an exonuclease-catalyzed digestion of the aptamer-cDNA sequence modified with MB-labelled, which acts as a signaling molecule. In the absence of OPN, the structure formed between the aptamer and aptamer-cDNA sequence prevent the degradation of the cDNA-sequence by Exo-I digestion. Upon, aptamer-OPN interaction, the cDNAsequence-MB-labelled will be liberated and susceptive to Exo-I action leading to the digestion of the cDNA sequence, allowing the MB tag to be captured by cucurbit[7]uril immobilized on the electrode, resulting in an electrochemical signal, detectable by SWV. This aptasensor presented high specificity, good reproducibility and a detection limit of $10.7 \mathrm{ng} / \mathrm{mL}$. These results are of utmost relevance to support the development of new biosensors able to detect and quantify OPN in biological samples and can be apply for the detection of multiple proteins, by modifying different cDNA-sequences with different tags. Hu et al. (2014) developed an ultrasensitive electrochemical aptasensor for the detection of MUC1, which is as mentioned before a useful marker for breast cancer. In the fabrication of this aptasensor, AuNPs and the enzyme HRP were used with labels and a GCE electrode was modified with multi-walled carbon nanotubes and streptavidin. The aptamer was modified with thiol at the $5^{\prime}$-end and with biotin at the $3^{\prime}$-end. The modified aptamer and HRP were then immobilized on the AuNPs (APT-AuNPs-HRP), allowing the bridges between the aptamer and the enzyme (HRP) to increase the signal amplification. After the aptamerMUC1 interaction, the aptamer was disrupted and the biotin exposed was captured by the streptavidin-modified electrode. This "signal-on" aptasensor exhibited good linear correlation dynamic ranges from $8.8 \mathrm{nM}$ to $353.3 \mathrm{nM}$ and a very low detection limit (2.2 nM). Likewise, Chen et al. (2015) also reported a signal-on electrochemical aptasensor for the same protein. The poly(o-phenylenediamine)-AuNPs (PoPDAuNPs) film was used as capture probe for the immobilization of aptamer-1. On the other hand, the AuNPs functionalized silica/multiwalled carbon nanotubes core-shell nanocomposites (AuNPs/SiO2@ MWCNTs) were used to enhance the surface area for immobilizing the secondary aptamer, as well as to load large amounts of electrochemical probe thionine (Thi). The presence of MUC1 induced the formation of one complex between the PoPD-AuNPs-APT1 and the Thi-AuNPs/ SiO2@MWCNTs-APT2. The current changes that resulted from the formation of such complex were registered by DPV and a detection limit of 1 pM was obtained. In comparison with the work carried out by Zhao et al. (2012) and Hu et al. (2014), this aptasensor showed better linear range and detection limit, since the AuNPs and MWCNTs facilitate electron transfer from Thi to electrode. For the detection and analysis of VEGF (biomarker associated with different types of cancer), Ravalli et al. (2015) reported an electrochemical single-use aptasensor. The proposed aptasensor was based on a sandwich assay using two different aptamers, AuNPs and an enzyme-amplified detection. The graphite screen-printed electrodes (GSPEs) were modified by electrodeposition of AuNPs for thiolated aptamer-1 immobilization. After aptamer-1VEGF recognition, the biotinylated aptamer 2 was added and the resulting complex was coupled with streptavidin-alkaline phosphatase for amplified detection. The electroactive product of the enzymatic reaction was detected by means of DPV. The "signal-on" aptasensor response was found to be linearly related to the target concentration between 0 and $250 \mathrm{nM}$; the detection limit was $30 \mathrm{nM}$, which was slightly worse than the examples previously mentioned. Shamsipur et al. (2015) also reported a label-free "signal-off" aptasensor to detect
VEGF but using a BSA-gold nanocluster/ionic liquid as platform, which offers a large surface area to immobilize the aptamer. Upon binding of the protein, a decrease in the current intensity was observed, mainly due to the target-induced folding of the aptamer, leading to a detection limit of $0.32 \mathrm{pM}$, which is much lower than the works reported by Ravalli et al. (2015) and Zhao et al. (2011b) possibly due to application of nanoclusters stabilized by BSA protein, which allow a large specific surface area, easy functionalization, low toxicity and good conductivity. For the detection of PDGF, another protein disease biomarker, Wang et al. (2009) described an electrochemical approach using a sandwich assay. The authors used AuNPs to increase the signal of the electrochemical probe. Using this approach, the sensitivity of the aptasensor was greatly increased allowing the detection of PDGF both in purified samples and in undiluted blood serum. Deng et al. (2013a,b) also developed an aptasensor to detect PDGF but using the enzyme-mediated direct electrochemistry of glucose oxidase (GOD). The GOD layer was adsorbed onto the electrode surface using a poly(diallyldimethylammonium chloride) (PDDA)-protected graphene-gold nanoparticles (P-Gra-AuNPs) composite and the aptamer was immobilized onto the gold nanoclusters (GNCs) deposited on the surface of GOD. This aptasensor showed high sensitivity and specificity for PDGF, as well as a very good reproducibility and stability.

Based in a dual signal amplification strategy, Bai et al. (2012) reported a sandwich assay for the simultaneous detection of PDGF and thrombin. The aptasensor was fabricated using AuNPs functionalized singlewalled carbon nanotubes (AuNPs@SWCNTs) as the biosensor platform to capture a large amount of primary aptamers and amplify the detection response. The redox probes toluidine blue ( $\mathrm{Tb})$ and Fc were attached onto the reduced graphene oxide sheets (rGS) coated with PtNPs (PtNPs-redox probes-rGS nanocomposites). The synthesized PtNPs-Tb/Fc-rGS nanocomposites were then used as carriers for glucose oxidase (GOD) and horseradish peroxidase (HRP) and the aptamer-2 (PDGF- and thrombin-binding), respectively. The linear range of PDGF was found to be 0.01 to $35 \mathrm{nM}$ with a detection limit of $8 \mathrm{pM}$, while the linear range was 0.02 to $45 \mathrm{nM}$ with a detection limit of $11 \mathrm{pM}$ for thrombin as obtained by DPV. The results clearly demonstrate that these dual signal amplification strategies lead to very low detection limits as compared to the previously discussed strategies (Sections 3.4 and 3.5).

Altogether, these studies highlight that the use of nanomaterials in the development of aptasensors allows an improvement of the sensibility in the detection of specific proteins (e.g. OPN, MUC1, PDGF and VEGF) and can hold a great promise for point-of-care diagnosis of genetic diseases and for the detection of cancer.

\section{Conclusions}

In the recent years, there has been an increasing interest in the use of aptasensors for the detection of protein disease biomarkers employing different immobilization techniques, design strategies and modes of detection. However, most of these aptasensors have been developed for in vitro detection of biomarkers, therefore the design of in vivo solutions should be a priority in the future.

The majority of cancer diseases are associated with the presence of more than one protein biomarker. Hence, further developments on the aptasensors field must involve the design of multiple detection sensors for different or even the same biomarkers, as these substances can be found in very low amounts in biological fluids. Multiple detection sensors would increase sensitivity and consequently provide more accurate information on biomarkers levels, thus improving the prognosis and treatment of diseases. The aptasensors arrays can be a good alternative offering the possibility of simultaneous measurements of a variety of targets, and thus shortening the time required for the analysis and decreasing the detection costs. Another alternative is the use of microchips and nanochips to allow miniaturization and integration of nanomaterials that enhance the surface area, as well as for signal 
amplification in the development of electrochemical aptasensors. However, the simultaneous detection of multiple targets (e.g. protein biomarkers) using voltammetric aptasensors arrays has seldom been reported.

The future of aptamer-based biosensors looks increasingly bright, yet many hurdles, such as lack of specific aptamers against protein biomarkers, lack of experience in multi-analyte detection and the complexity of clinical samples, remain to be solved especially in the field of biomedicine and point-of-care diagnostics.

\section{Conflict of interest}

No conflict of interest declared.

\section{Acknowledgements}

The authors acknowledge the financial support from the Strategic funding of UID/BIO/04469/2013 unit, from Project POCI-01-0145FEDER-006984 - Associate Laboratory LSRE-LCM funded by FEDER funds through COMPETE2020 - Programa Operacional Competitividade e Internacionalização (POCI) - and by national funds through FCT Fundação para a Ciência e a Tecnologia and project ref. RECI/BBB-EBI/ 0179/2012 (project number FCOMP-01-0124-FEDER-027462) and S. Meirinhos's doctoral grant (ref SFRH/BD/65021/2009) funded by Fundação para a Ciência e a Tecnologia.

\section{References}

Arshak, K., Velusamy, V., Korostynska, O., Oliwa-Stasiak, K., Adley, C., 2009. Conducting polymers and their applications to biosensors: emphasizing on foodborne pathogen detection. IEEE Sensors J. 9, 1942-1951.

Bai, L., Yuan, R., Chai, Y., Zhuo, Y., Yuan, Y., Wang, Y., 2012. Simultaneous electrochemical detection of multiple analytes based on dual signal amplification of single-walled carbon nanotubes and multi-labeled graphene sheets. Biomaterials 33, 1090-1096.

Balamurugan, S., Obubuafo, A., Soper, S.A., Spivak, D.A., 2008. Surface immobilization methods for aptamer diagnostic applications. Anal. Bioanal. Chem. 390, 1009-1021.

Baldrich, E., Radi, A.E., Dondapati, S., Sa, L., Katakis, I., Sullivan, C.K.O., Sanchez, J.L.A. Sanchez, L., 2006. Electronic off-on molecular switch for rapid detection of thrombin. Electroanalysis 18, 1957-1962.

Bang, G.S., Cho, S., Kim, B., 2005. A novel electrochemical detection method for aptamer biosensors. Biosens. Bioelectron. 21, 863-870

Cao, Y., Chen, D., Chen, W., Yu, J., Chen, Z., Li, G., 2014. Aptamer-based homogeneous protein detection using cucurbit[7]uril functionalized electrode. Anal. Chim. Acta 812, 45-49.

Centi, S., Tombelli, S., Minunni, M., Mascini, M., 2007. Aptamer-based detection of plasma proteins by an electrochemical assay coupled to magnetic beads. Anal. Chem. 79, 1466-1473.

Centi, S., Sanmartin, B., Tombelli, S., Palchetti, I., 2009. Detection of C reactive protein (CRP) in serum by an electrochemical aptamer-based sandwich assay. Electroanalysis 21, 1309-1315.

Chen, X., Zhang, Q., Qian, C., Hao, N., Xu, L., Yao, C., 2015. Electrochemical aptasensor for mucin 1 based on dual signal amplification of poly(o-phenylenediamine) carrier and functionalized carbon nanotubes tracing tag. Biosens. Bioelectron. 64, 485-492.

Cheng, A.K.H., Ge, B., Yu, H.-Z., 2007. Aptamer-based biosensors for label-free voltammetric detection of lysozyme. Anal. Chem. 79, 5158-5164.

Cheng, A.K.H., Sen, D., Yu, H., 2009. Design and testing of aptamer-based electrochemical biosensors for proteins and small molecules. Bioelectrochemistry 77, 1-12.

Cho, E.J., Lee, J., Ellington, A.D., 2009. Applications of aptamers as sensors. Annu. Rev. Anal. Chem. 2, 241-264.

Chung, D.-J., Kim, K.-C., Choi, S.-H., 2011. Electrochemical DNA biosensor based on avidinbiotin conjugation for influenza virus (type A) detection. Appl. Surf. Sci. 257, 9390-9396.

Citartan, M., Gopinath, S.C.B., Tominaga, J., Tan, S.-C., Tang, T.-H., 2012. Assays for aptamer-based platforms. Biosens. Bioelectron. 34, 1-11.

Csordas, A., Gerdon, A.E., Adams, J.D., Qian, J., Oh, S.S., Xiao, Y., Soh, H.T., 2010. Detection of proteins in serum by micromagnetic aptamer PCR (MAP) technology. Angew. Chem. 49, 355-358.

Darmostuk, M., Rimpelová, S., Gbelcová, H., Ruml, T., 2015. Current approaches in SELEX: an update to aptamer selection technology. Biotechnol. Adv. 33, 1141-1161.

Degefa, T.H., Kwak, J., 2008. Label-free aptasensor for platelet-derived growth factor (PDGF) protein. Anal. Chim. Acta 613, 163-168.

de-los-Santos-Álvarez, N., Lobo-Castañón, M.J., Miranda-Ordieres, A.J., Tuñón-Blanco, P., 2008. Aptamers as recognition elements for label-free analytical devices. TrAC Trends Anal. Chem. 27, 437-446.

Deng, D., Shi, Y., Feng, H., Chen, Q., Li, D., Liu, L., 2013a. Label-free electrochemical sensing platform for the detection of protease. Int. J. Electrochem. Sci. 8, 6933-6940.
Deng, K., Xiang, Y., Zhang, L., Chen, Q., Fu, W., 2013b. An aptamer-based biosensing platform for highly sensitive detection of platelet-derived growth factor via enzyme-mediated direct electrochemistry. Anal. Chim. Acta 759, 61-65.

Ding, C., Ge, Y., Lin, J.-M., 2010. Aptamer based electrochemical assay for the determination of thrombin by using the amplification of the nanoparticles. Biosens. Bioelectron. $25,1290-1294$.

Dua, P., Kim, S., Lee, D.-K., 2011. Nucleic acid aptamers targeting cell-surface proteins Methods 54, 215-225.

Ellington, A.D., Szostak, J.W., 1990. In vitro selection of RNA molecules that bind specific ligands. Nature 346, 818-822.

Erdem, A., Karadeniz, H., Mayer, G., Famulok, M., Caliskan, A., 2009. Electrochemical sensing of aptamer-protein interactions using a magnetic particle assay and single-use sensor technology. Electroanalysis 21, 1278-1284.

Famulok, M., Mayer, G., 2011. Aptamer modules as sensors and detectors. Acc. Chem. Res. 44, 1349-1358.

Feng, K., Sun, C., Kang, Y., Chen, J., Jiang, J.-H., Shen, G.-L., Yu, R.-Q., 2008. Label-free electrochemical detection of nanomolar adenosine based on target-induced aptamer displacement. Electrochem. Commun. 10, 531-535.

Ferreira, A., Fugivara, C., Yamanaka, H., Benedetti, A., 2011. Preparation and characterization of imunosensors for disease diagnosis. Biosensors for Health, Environment and Biosecurity, p. 540.

Grieshaber, D., MacKenzie, R., Voeroes, J., Reimhult, E., 2008. Electrochemical biosensorssensor principles and architectures. Sensors 8, 1400-1458.

Guo, K.-T., Paul, A., Schichor, C., Ziemer, G., Wendel, H.P., 2008. CELL-SELEX: novel perspectives of aptamer-based therapeutics. Int. J. Mol. Sci. 9, 668-678.

Han, K., Chen, L., Lin, Z., Li, G., 2009. Target induced dissociation (TID) strategy for the development of electrochemical aptamer-based biosensor. Electrochem. Commun. 11 $157-160$.

Han, K., Liang, Z., Zhou, N., 2010. Design strategies for aptamer-based biosensors. Sensors (Basel) 10, 4541-4557.

Hanash, S.M., 2011. Why have protein biomarkers not reached the clinic? Genome Med 3, 66-72.

Hayat, A., Marty, J.L., 2014. Aptamer based electrochemical sensors for emerging environmental pollutants. Front. Chem. 2, 42-68.

Hernandez, F.J., Ozalp, V.C., 2012. Graphene and other nanomaterial-based electrochemical aptasensors. Biosensors 2, 1-14.

Hianik, T., Wang, J., 2009. Electrochemical aptasensors - recent achievements and perspectives. Electroanalysis 21, 1223-1235.

Hianik, T., Ostatná, V., Zajacová, Z., Stoikova, E., Evtugyn, G., Zajacova, Z., Ostatna, V., 2005 Detection of aptamer - protein interactions using QCM and electrochemical indicator methods. Bioorg. Med. Chem. 15, 291-295.

Hianik, T., Ostatná, V., Sonlajtnerova, M., Grman, I., 2007. Influence of ionic strength, pH and aptamer configuration for binding affinity to thrombin. Bioelectrochemistry 70 , 127-133.

Hong, P., Li, W., Li, J., 2012. Applications of aptasensors in clinical diagnostics. Sensors (Basel) 12, 1181-1193.

Hu, R., Wen, W., Wang, Q., Xiong, H., Zhang, X., Gu, H., Wang, S., 2014. Novel electrochemical aptamer biosensor based on an enzyme-gold nanoparticle dual label for the ultrasensitive detection of epithelial tumour marker MUC1. Biosens. Bioelectron. 53, 384-389.

Jo, H., Gu, H., Jeon, W., Youn, H., Her, J., Kim, S.K., Lee, J., Shin, J.H., Ban, C., 2015. Electrochemical aptasensor of cardiac troponin i for the early diagnosis of acute myocardial infarction. Anal. Chem. 87, 9869-9875.

Kang, Y., Feng, K.-J., Chen, J., Jiang, J., Shen, G., Yu, R., 2008. Electrochemical detection of thrombin by sandwich approach using antibody and aptamer. Bioelectrochemistry 73, 76-81.

Kim, Y.S., Gu, M.B., 2014. Advances in aptamer screening and small molecule aptasensors. Adv. Biochem. Eng. Biotechnol. 140, 29-67.

Kim, Y.S., Lee, S.J., Gu, M.B., 2008. Electrochemical aptamer-based biosensors. BioChip J. 2 $175-182$.

Kumar, J., D'Souza, S., 2012. Biosensors for environmental and clinical monitoring. Barc Newsl. 324, 34-38.

Kuwahara, M., Sugimoto, N., 2010. Molecular evolution of functional nucleic acids with chemical modifications. Molecules 15, 5423-5444.

Labib, M., Berezovski, M.V., 2014. Electrochemical aptasensors for microbial and vira pathogens. Adv. Biochem. Eng. Biotechnol. 140, 155-181.

Lai, R.Y.R.Y., Plaxco, K.W.K.W., Heeger, A.J.A.J., 2007. Aptamer-based electrochemical detection of picomolar platelet-derived growth factor directly in blood serum. Anal. Chem. 79, 229-233.

Lakhin, A.V., Tarantul, V.Z., Gening, L.V., 2013. Aptamers: problems, solutions and prospects. Acta Nat. 5, 34-43.

Lee, J.-O., So, H.-M., Jeon, E.-K., Chang, H., Won, K., Kim, Y.H., 2008. Aptamers as molecular recognition elements for electrical nanobiosensors. Anal. Bioanal. Chem. 390 1023-1032.

Li, Y., Bao, J., Han, M., Dai, Z., Wang, H., 2011a. A simple assay to amplify the electrochemical signal by the aptamer based biosensor modified with CdS hollow nanospheres. Biosens. Bioelectron. 26, 3531-3535.

Li, Y., Han, M., Bai, H., Wu, Y., Dai, Z., Bao, J. 2011b. A sensitive electrochemical aptasensor based on water soluble CdSe quantum dots (QDs) for thrombin determination. Electrochim. Acta 56, 7058-7063.

Lim, Y.C., Kouzani, A.Z., Duan, W., 2010. Aptasensors: a review. J. Biomed. Nanotechnol. 6, 93-105.

Liu, C.-C., 2000. Electrochemical sensors. In: Bronzino, J.D. (Ed.), The Biomedical Engineering Handbook. CRC Press LLC.

Liu, Y., Tuleouva, N., Ramanculov, E., Revzin, A., 2010. Aptamer-based electrochemica biosensor for interferon gamma detection. Anal. Chem. 82, 8131-8136. 
Liu, X., Li, W., Xu, X., Zhou, J., Nie, Z., 2012. Electrochemical aptamer sensor for small molecule assays. Methods Mol. Biol. 800, 119-132.

Liu, Y., Zhou, Q., Revzin, A., 2013. An aptasensor for electrochemical detection of tumor necrosis factor in human blood. Analyst 138, 4321-4326.

Lu, Y., Zhu, N., Yu, P., Mao, L., 2008. Aptamer-based electrochemical sensors that are not based on the target binding-induced conformational change of aptamers. Analyst 133, 1256-1260.

Ma, F., Ho, C., Cheng, A.K.H., Yu, H.Z., 2013. Immobilization of redox-labeled hairpin DNA aptamers on gold: electrochemical quantitation of epithelial tumor marker mucin 1. Electrochim. Acta 110, 139-145.

Marks, R.S., Abdulhalim, I., 2015. Nanomaterials for Water Management: Signal Amplification for Biosensing From Nanostructures volume 4. Press, CRC.

Meirinho, S.G., Dias, L.G., Peres, A.M., Rodrigues, L.R., 2015. Development of an electrochemical RNA-aptasensor to detect human osteopontin. Biosens. Bioelectron. 71, 332-341.

Meyer, C., Hahn, U., Rentmeister, A., 2011. Cell-specific aptamers as emerging therapeutics. J. Nucleic Acids 2011, 1-18, 904750

Mi, Z., Guo, H., Russell, M.B., Liu, Y., Sullenger, B.A., Kuo, P.C., 2009. RNA aptamer blockade of osteopontin inhibits growth and metastasis of MDA-MB231 breast cancer cells. Mol. Ther. 17, 153-161.

Monošík, R., Stred'anský, M., Šturdík, E., 2012. Biosensors - classification, characterization and new trends. Acta Chim. Slov. 5, 109-120.

Nguyen, T.H., Hilton, J.P., Lin, Q., 2009. Emerging applications of aptamers to micro-and nanoscale biosensing. Microfluid. Nanofluid. 6, 347-362.

Nimse, S., Song, K., Sonawane, M., Sayyed, D., Kim, T., 2014. Immobilization techniques for microarray: challenges and applications. Sensors 14, 22208-22229.

Ostatná, V., Vaisocherová, H., Homola, J., Hianik, T., 2008. Effect of the immobilisation of DNA aptamers on the detection of thrombin by means of surface plasmon resonance. Anal. Bioanal. Chem. 391, 1861-1869.

Palchetti, I., Mascini, M., 2012. Electrochemical nanomaterial-based nucleic acid aptasensors. Anal. Bioanal. Chem. 402, 3103-3114.

Paniel, N., Baudart, J., Hayat, A., Barthelmebs, L., 2013. Aptasensor and genosensor methods for detection of microbes in real world samples. Methods 64, 229-240.

Park, S., Ahn, J.Y., Jo, M., Lee, D., Lis, J.T., Craighead, H.G., Kim, S., 2009. Selection and elution of aptamers using nanoporous sol-gel arrays with integrated microheaters. Lab Chip 9, 1206-1212.

Potyrailo, R.A., Conrad, R.C., Ellington, A.D., Hieftje, G.M., 1998. Adapting selected nucleic acid ligands aptamers to biosensors. Anal. Chem. 70, 3419-3425.

Prieto-Simón, B., Campàs, M., Marty, J.-L., 2010. Electrochemical aptamer-based sensors. Bioanal. Rev. 1, 141-157.

Radi, A.-E., 2011. Electrochemical aptamer-based biosensors: recent advances and perspectives. Int. J. Electrochem. 2011, 1-17, 863196.

Radi, A., Lluis, J., Sa, A., Baldrich, E., Sullivan, C.K.O., 2006. Reagentless, reusable, ultrasensitive electrochemical molecular beacon aptasensor. J. Am. Chem. Soc. 128, 117-124

Radom, F., Jurek, P.M., Mazurek, M.P., Otlewski, J., Jeleń, F., 2013. Aptamers: molecules of great potential. Biotechnol. Adv. 31, 1260-1274.

Rahman, M.A., Kumar, P., Park, D.S., Shim, Y.B., 2008. Electrochemical sensors based on organic conjugated polymers. Sensors 8, 118-141.

Ravalli, A., Rivas, L., De La Escosura-Muñiz, A., Pons, J., Merkoçi, A., Marrazza, G., 2015. A DNA aptasensor for electrochemical detection of vascular endothelial growth factor. J. Nanosci. Nanotechnol. 15, 3411-3416.

Rodríguez, M.C., Rivas, G.A., 2009. Label-free electrochemical aptasensor for the detection of lysozyme. Talanta 78, 212-216.

Ronkainen, N.J., Halsall, H.B., Heineman, W.R., 2010. Electrochemical biosensors. Chem. Soc. Rev. 39, 1747-1763.

Saberian, M., Hamzeiy, H., Aghanejad, A., Asgari, D., 2011. Aptamer-based nanosensors: juglone as an attached-redox molecule for detection of small molecules. Bioimpacts $1,31-36$.

Sadik, O.A., Aluoch, A.O., Zhou, A., 2009. Status of biomolecular recognition using electrochemical techniques. Biosens. Bioelectron. 24, 2749-2765.

Sánchez, J.L., Baldrich, E., Radi, A.E., Dondapati, S., Sa, L., Katakis, I., Sullivan, C.K.O., Sanchez, J.L.A., Sanchez, L., 2006. Electronic off-on molecular switch for rapid detection of thrombin. Electroanalysis 18, 1957-1962.

Santosh, B., Yadava, P.K., 2014. Nucleic acid aptamers: research tools in disease diagnostics and therapeutics. Biomed. Res. Int. 2014, 1-13, 540451.

Sassolas, A., Leca-Bouvier, B.D., Blum, L.J., 2008. DNA biosensors and microarrays. Chem. Rev. 108, 109-139.

Sassolas, A., Blum, L.J.J.J., Leca-Bouvier, B.D.D.D., Lyon, D., 2009. Electrochemical aptasensors. Electroanalysis 21, 1237-1250.

Sett, A., Das, S., Sharma, P., Bora, U., 2012. Aptasensors in health, environment and food safety monitoring. Open J. Appl. Biosen. 01, 9-19.

Shamah, S.M., Healy, J.M., Cload, S.T., 2008. Complex target SELEX. Acc. Chem. Res. 41, 130-138.

Shamsipur, M., Farzin, L., Amouzadeh Tabrizi, M., Molaabasi, F., 2015. Highly sensitive label free electrochemical detection of VGEF165 tumor marker based on "signal off" and "signal on" strategies using an anti-VEGF165 aptamer immobilized BSA-gold nanoclusters/ionic liquid/glassy carbon electrode. Biosens. Bioelectron. 74, 369-375.

Song, S., Wang, L., Li, J., Zhao, J., Fan, C., 2008. Aptamer-based biosensors. Anal. Chem. 27, $108-117$.

Song, K.-M., Lee, S., Ban, C., 2012. Aptamers and their biological applications. Sensors (Basel) 12, 612-631.
Stoltenburg, R., Reinemann, C., Strehlitz, B , 2007. SELEX - a (r)evolutionary method to generate high-affinity nucleic acid ligands. Biomol. Eng. 24, 381-403.

Strehlitz, B., Nikolaus, N., Stoltenburg, R., 2008. Protein detection with aptamer biosensors. Sensors 8, 4296-4307.

Suprun, E., Shumyantseva, V., Bulko, T., Rachmetova, S., Rad'ko, S., Bodoev, N., Archakov, A., 2008. Au-nanoparticles as an electrochemical sensing platform for aptamerthrombin interaction. Biosens. Bioelectron. 24, 831-836.

Syed, M.A., Pervaiz, S., 2010. Advances in aptamers. Oligonucleotides 20, 215-224.

Taleat, Z., Cristea, C., Marrazza, G., Mazloum-Ardakani, M., Sandulescu, R., 2014. Electrochemical immunoassay based on aptamer-protein interaction and functionalized polymer for cancer biomarker detection. J. Electroanal. Chem. 717-718, 119-124.

Thévenot, D.R., Toth, K., Durst, R.A., Wilson, G.S., Thévenot, D.R., 1999. Electrochemical biosensors: recommended definitions and classification (technical report). Pure Appl. Chem. 71, 2333-2348.

Thévenot, D.R.D.R. Toth, K., Durst, R.A.R.A, Wilson, G.S.G. 2001. Electrochemical biosensors: recommended definitions and classification. Biosens. Bioelectron. 16, 121-131.

Tombelli, S., Minunni, M., Luzi, E., Mascini, M., 2005. Aptamer-based biosensors for the detection of HIV-1 Tat protein. Bioelectrochemistry 67, 135-141.

Tothill, I.E., 2009. Biosensors for cancer markers diagnosis. Semin. Cell Dev. Biol. 20, 55-62.

Tuerk, C., Gold, L., 1990. Systematic evolution of ligands by exponential enrichment: RNA ligands to bacteriophage T4 DNA polymerase. Science 80 (249), 505-510.

Velasco-Garcia, M.N., Missailidis, S., 2009. New trends in aptamer-based electrochemical biosensors. Gene Ther. Mol. Biol. 13, 1-9.

Velusamy, V., Arshak, K., Korostynska, O., Oliwa, K., Adley, C., 2010. An overview of foodborne pathogen detection : in the perspective of biosensors. Biotechnol. Adv. 28, 232-254.

Vidotti, M., Carvalhal, R.F., Mendes, R.K., Ferreira, D.C.M., Kubota, L.T., 2011. Biosensors based on gold nanostructures. J. Braz. Chem. Soc. 22, 3-20.

Vikesland, P.J., Wigginton, K.R., 2010. Nanomaterial enabled biosensors for pathogen monitoring - a review. Environ. Sci. Technol. 44, 3656-3669.

Viswanathan, S., Radecki, J., 2008. Nanomaterials in electrochemical biosensors for food analysis-a review. Pol. J. Food Nutr. 58, 157-164.

Wang, J., Meng, W., Zheng, X., Liu, S., Li, G., 2009. Combination of aptamer with gold nanoparticles for electrochemical signal amplification: application to sensitive detection of platelet-derived growth factor. Biosens. Bioelectron. 24, 1598-1602.

Wang, Y, Yuan, R., Chai, Y, Yuan, Y, 2011. A multi-amplification aptasensor for highly sensitive detection of thrombin based on high-quality hollow CoPt nanoparticles decorated graphene. Biosens. Bioelectron. 30, 61-66.

Wang, Y., Xiao, Y., Ma, X., Li, N., Yang, X., 2012. Label-free and sensitive thrombin sensing on a molecularly grafted aptamer on graphene. Chem. Commun. 48, 738-740.

Wang, Q., Zhou, Z., Zhai, Y., Zhang, L., Hong, W., Zhang, Z., Dong, S., 2015. Label-free aptamer biosensor for thrombin detection based on functionalized graphene nanocomposites. Talanta 141, 247-252.

Wei, F., Patel, P., Liao, W., Chaudhry, K., Zhang, L., Arellano-Garcia, M., Hu, S., Elashoff, D., Zhou, H., Shukla, S., Shah, F., Ho, C.-M., Wong, D.T., 2009. Electrochemical sensor for multiplex biomarkers detection. Clin. Cancer Res. 15, 4446-4452.

Xiao, Y., Lubin, A.A., Heeger, A.J., Plaxco, K.W., 2005a. Label-free electronic detection of thrombin in blood serum by using an aptamer-based sensor. Angew. Chem. Int. Ed. Eng. 44, 5456-5459.

Xiao, Y., Piorek, B.D., Plaxco, K.W., Heeger, A.J., 2005b. A reagentless signal-on architecture for electronic, aptamer-based sensors via target-induced strand displacement. J. Am. Chem. Soc. 127, 17990-17991.

Xu, Y., Cheng, G., He, P., Fang, Y., 2009. A review: electrochemical aptasensors with various detection strategies. Electroanalysis 21, 1251-1259.

Xu, Y.-Y., Zhang, Y.-Y., Lu, W.-F., Mi, Y.-J., Chen, Y.-Q., 2015. Prognostic value of osteopontin expression in breast cancer: a meta-analysis. Mol. Clin. Oncol. 3, 357-362.

Yuan, Y., Gou, X., Yuan, R., Chai, Y., Zhuo, Y., Ye, X., Gan, X., 2011. Graphene-promoted 3,4,9,10-perylenetetracarboxylic acid nanocomposite as redox probe in label-free electrochemical aptasensor. Biosens. Bioelectron. 30, 123-127.

Zhang, F., Chen, J., 2010. Discovery of pathway biomarkers from coupled proteomics and systems biology methods. BMC Genomics 11, S12.

Zhang, S., Wright, G., Yang, Y., 2000. Materials and techniques for electrochemical biosensor design and construction. Biosens. Bioelectron. 15, 273-282.

Zhang, Y., Huang, Y., Jiang, J., 2007. Electrochemical aptasensor based on proximity-dependent surface hybridization assay for single-step, reusable, sensitive protein detection. J. Am. Chem. Soc. 129, 15448-15449.

Zhang, Y.L., Pang, P.-F., Jiang, J.H., Shen, G.L., Yu, R.Q., 2009. Electrochemical aptasensor based on proximity-dependent surface hybridization assay for protein detection. Electroanalysis $21,1327-1333$.

Zhao, J., Zhang, Y., Li, H., Wen, Y., Fan, X., 2011a. Ultrasensitive electrochemical aptasensor for thrombin based on the amplification of aptamer-AuNPs-HRP conjugates. Biosens. Bioelectron. 26, 2297-2303.

Zhao, S., Yang, W., Lai, R.Y., 2011b. A folding-based electrochemical aptasensor for detection of vascular endothelial growth factor in human whole blood. Biosens. Bioelectron. 26, 2442-2447.

Zhao, J., He, X., Bo, B., Liu, X., Yin, Y., Li, G., 2012. A “signal-on" electrochemical aptasensor for simultaneous detection of two tumor markers. Biosens. Bioelectron. 34, 249-252.

Zhou, L., Wang, M.-H., Wang, J.-P., Ye, Z.-Z., 2011. Application of biosensor surface immobilization methods for aptamer. Chin. J. Anal. Chem. 39, 432-438.

Zhou, W., Huang, P.-J.J., Ding, J., Liu, J., 2014. Aptamer-based biosensors for biomedical diagnostics. Analyst 139, 2627-2640. 